\title{
Structural Diversity in Conserved Regions Like the DRY-Motif among Viral 7TM Receptors-A Consequence of Evolutionary Pressure?
}

\author{
Ann-Sofie Mølleskov Jensen, ${ }^{1}$ Alexander Hovard Sparre-Ulrich, ${ }^{1}$ \\ Nicholas Davis-Poynter, ${ }^{2}$ and Mette Marie Rosenkilde ${ }^{1}$ \\ ${ }^{1}$ Laboratory for Molecular Pharmacology, Department of Neuroscience and Pharmacology, The Panum Institute, \\ University of Copenhagen, Building 18.5, Blegdamsvej 3, 2200-Copenhagen N, Denmark \\ ${ }^{2}$ Sir Albert Sakzewski Virus Research Centre (SASVRC), Royal Children's Hospital/Clinical Medical Virology Centre (CMVC), \\ University of Queensland, St Lucia, QLD 4072, Australia
}

Correspondence should be addressed to Mette Marie Rosenkilde, rosenkilde@sund.ku.dk

Received 15 March 2012; Accepted 31 May 2012

Academic Editor: Rika Draenert

Copyright (C) 2012 Ann-Sofie Mølleskov Jensen et al. This is an open access article distributed under the Creative Commons Attribution License, which permits unrestricted use, distribution, and reproduction in any medium, provided the original work is properly cited.

\begin{abstract}
Several herpes- and poxviruses have captured chemokine receptors from their hosts and modified these to their own benefit. The human and viral chemokine receptors belong to class A 7 transmembrane (TM) receptors which are characterized by several structural motifs like the DRY-motif in TM3 and the C-terminal tail. In the DRY-motif, the arginine residue serves important purposes by being directly involved in G protein coupling. Interestingly, among the viral receptors there is a greater diversity in the DRY-motif compared to their endogenous receptor homologous. The C-terminal receptor tail constitutes another regulatory region that through a number of phosphorylation sites is involved in signaling, desensitization, and internalization. Also this region is more variable among virus-encoded 7TM receptors compared to human class A receptors. In this review we will focus on these two structural motifs and discuss their role in viral 7TM receptor signaling compared to their endogenous counterparts.
\end{abstract}

\section{Introduction}

Seven transmembrane (7TM) receptors constitute the largest superfamily of membrane proteins and function as important mediators of extracellular signals to intracellular responses. The chemical diversity of the endogenous ligands is tremendous ranging from small simple chemical entities like photons, ions, and nucleotides, to more complex small ligands like monoamines and peptides, and larger proteins, glycoproteins, and lipids. The 7TM receptors are divided into five classes of which class A or rhodopsin-like receptors is the dominating class [1]. The receptors are characterized by seven membrane-spanning $\alpha$-helices as well as coupling to $\mathrm{G}$ proteins; hence, the name is $\mathrm{G}$ protein coupled receptors (GPCRs). (In this review we will use the term 7TM receptors instead of GPCRs as these receptors also signal trough non$\mathrm{G}$ protein-dependent pathways, like $\beta$-arrestin-mediated signaling [2].) Signaling by 7TM receptors through G proteins leads to, for example, either inhibition $\left(\mathrm{G}_{\alpha i}\right)$ or activation $\left(\mathrm{G}_{\alpha s}\right)$ of adenylyl cyclase and cAMP production, activation of phospholipase $\mathrm{C}$ with inositol triphosphate turnover $\left(\mathrm{G}_{\alpha q}\right)$, or activation of RhoGEF $\left(\mathrm{G}_{\alpha 12 / 13}\right)$ depending on which $\mathrm{G}$ protein the receptor is activating [3]. Furthermore, the $\mathrm{G}_{\beta \gamma}$ subunit is also involved in signaling and the 7TM receptors also signal via $G$ protein-independent pathways like MAPkinase activation-mediated by $\beta$-arrestins [4].

Despite the structural diversity in the repertoire of the endogenous 7TM receptor agonists, the conformational changes that occur upon receptor activation are believed to be overall identical. Thus, as the last two decades of biochemical and biophysical studies indicate, TM6, and to a minor degree TM7 and TM3, undergo conformational rearrangement during receptor activation $[5,6]$. Centered around the highly conserved proline in the middle of TM6 (position VI:15 or 6.50) TM6 is believed to perform movements that results in space creation thereby permitting binding 
of intracellular signal transduction molecules like $\mathrm{G}$ proteins and $\beta$-arrestins [7]. (The numbering of amino acids in the helices is provided according to two numbering systems: the generic numbering system suggested by Schwartz [8], followed by the numbering system of Ballesteros and Weinstein [9],) Several crystal structures of 7TM receptors have been presented within the last decade initiated by the structure of bovine rhodopsin [10] followed by the adrenergic receptors [11-15], the adenosine receptors [16-18], additional rhodopsin variants [19-21], muscarinic receptors, [22, 23] and several others [24-26] including the chemokine receptor CXCR4 [27]. In the recent years, crystal structures of not only inactive, but also active 7TM receptors, have been identified. Thus, in the agonist-bound $\beta 2$-adrenergic receptor, a relatively large rearrangement of the lower segments of TM6 is observed, when compared to the corresponding inactive structure [13-15]. This structural feature is also observed in the crystal structure of opsin in complex with a $G$ protein peptide fragment upon comparison with dark-state rhodopsin $[21,28]$. The overall arrangement of the seven transmembrane $\alpha$-helices delineate the main binding pocket, and most studies in the search of functionally important residues have focused on amino acids facing this main binding pocket (delimited by TM3, TM4, TM5, TM6, and in part TM7). This is with good reason as most small molecule ligands interact with residues in this pocket $[11,12,29]$. Furthermore, most conserved microswitches of functional importance also face the main binding pocket. This includes ArgIII:26 (3.50), which is part of the conserved DRY-motif in TM3, the rotameric toggle switch TrpVI:13 (6.48), which is part of the CWxP-motif in TMVI, and TyrVII:20 (7.53), which is part the NPxxY-motif in TMVII-all of which play crucial roles during receptor activation [30, 31]. However, also residues in the region delimited by TM1, TM2, TM3, and TM7 (the so-called minor binding pocket) function as regulatory switches or major ligand anchor points [3234].

The DRY-motif is the most conserved motif among the microswitches mentioned above (Figures 2(a) and 2(c)) $[21,30]$ and has been shown to directly interact with the $\mathrm{G}$ protein in a recent crystal structure of the $\beta 2$-adrenergic receptor in complex with the $\mathrm{G}_{\alpha s}$-subunit-a crystal that displayed the actual signaling complex and uncovered the importance of both the DRY-motif and the NPxxY-motif in receptor activation $[14,35]$. While the overall interaction between the $\mathrm{G}$ protein and the receptor is mainly hydrophobic within the transmembrane core, the ArgIII:26 (3.50) is sandwiched between a Tyr in the G protein and TyrVI:20 (7.53) of the NPxxY-motif, highlighting the importance of concerted action of both motifs $[14,35]$.

The positively charged ArgIII:26 (3.50) has been proposed to be involved in other conformational constrains of importance for receptor activation. Thus, an inactivating salt bridge (a so-called ionic lock) has been suggested between the Arg and another conserved residue, the acidic GluVI:05 (6.30) in intracellular loop 3 (ICL3) [36]. This ionic lock is broken during receptor activation where TyrVI:20 (7.53) rotates towards the helix bundle as seen in the active crystal structures of both rhodopsin [21] and the $\beta 2$-adrenergic receptor irreversibly bound to an agonist [37] or stabilized by a nanobody [13]. However, as the GluVI:-05 (6.30) is only conserved among $25 \%$ of all class A receptors [14, $35]$, and not present in any of the chemokine receptors [38], the molecular interactions involved in conformational constraining of inactive receptor states and the role of ArgIII:26 (3.50) must be different in receptors without GluVI:-05(6.30). Finally, the DRY-motif interacts with ICL2 of the receptor, thereby stabilizing a position of this loop capable of interacting with a hydrophobic pocket on the $G$ protein and directly linking the highly conserved DRY-motif to the receptor/G protein interaction [14].

Another important region for receptor activity is the intracellular C-terminal tail of the 7TM receptors as it contains phosphorylation sites and other regulatory recognition motifs necessary for desensitization by $G$ proteincoupled receptor kinases (GRKs), $\beta$-arrestin recruitment and signaling, internalization and receptor recycling, and for other means of signal regulation [39]. These two receptor motifs will be the focus of the current review, where we will compare the structural and functional properties, degree of conservation, and functional diversity of the two motifs between class A 7TM receptors encoded by viruses and endogenously encoded 7TM receptors. Most of the virusencoded 7TM receptors belong to the chemokine subfamily [40] and consequently extra attention will be directed towards the viral molecular piracy within the chemokine system and the endogenous chemokine receptors.

\section{The Chemokine System}

The chemokine system plays an important role in the human immune defense against pathogens such as viruses since the chemokines (abbreviated from chemotactic cytokines) are involved in leukocyte migration during inflammation and also control activation and differentiation of lymphoid cells $[41,42]$. The chemokine receptors belong to class A 7TM receptors and comprise the largest subfamily within this group with 19 different endogenous chemokine receptors and up to 50 chemokine ligands [43]. The chemokines are divided into four subfamilies depending on the presence or absence of residues between the first two of usually four conserved cysteines: the CXC (CXCL1-16) and CC (CCL128) chemokines along with the CX3C (CX3CL1) and XC (XCL1) chemokines $[44,45]$. The CXC chemokines are further divided based on an ELR-motif prior to the CXCmotif. (In the following, the "novel" systematic chemokine nomenclature is used [44]) ELR CXC chemokines are induced under acute and chronic inflammation, play an angiogenic role, and mainly attract neutrophils while the non-ELR CXC chemokines exert their effect on lymphocytes and are more constitutively expressed as well as being angiostatic or angiomodulatory [46, 47]. The chemokine receptors are likewise divided into four groups in accordance with the classification of their preferred ligands $[44,48]$. The interaction between chemokine and receptor range from high selectivity to large promiscuity; although not cross-interacting with other subfamilies. The main signaling 
pathway of the endogenous chemokine receptors is via $\mathrm{G}_{\alpha i}$ leading to calcium release and chemotaxis [49].

\section{The Virus-Encoded 7TM Receptors}

Considering the role of chemokines in the immune system it is not surprising that several viruses, by an act of molecular piracy of host genes, encode chemokines and/or chemokine receptors in their genomes. It is primarily the large poxviruses and the $\beta$ - and $\gamma$-herpesviruses which encode chemokine receptors (and ligands) [50], however also the retrovirus HIV utilizes the endogenous chemokine system by using the two chemokine receptors CCR5 and CXCR4 as cell-entry co-factors together with CD4 during infection and spread $[42,51]$. Also the viral CC (and CX3C) chemokine receptor homolog US28 (described further below) encoded by HCMV (human cytomegalovirus) has been implicated as a HIV cell-entry co-factor [52]. The majority of the viral receptors have structural features in common with the endogenous chemokine receptors in spite of having a sequence identity to these of only $25-59 \%$ [42]. However, compared to the endogenous chemokine receptors, the viral receptors show a vast divergence in their signaling capacities as well as ligand specificity with constitutive activity being typical for the viral receptors, unlike the endogenous chemokine receptors [53-57]. Constitutive activity also occurs among endogenous non-chemokine receptors, as shown for a few receptors [58]; however an increasing number of examples illustrate that the range of naturallyoccurring constitutively activating mutations are tightly associated with disease or a particular phenotype [58]. This includes mutations in the melanocortin 1 receptor (MC1R; associated with melanism, [59]), MC4R (obesity, [60]), the ghrelin receptor (short stature, [61]) and rhodopsin (retinitis pigmentosa, [62]) among others.

Furthermore, besides being constitutively active, the viral receptors also signal promiscuously through many pathways, as compared to the predominant $\mathrm{G}_{\alpha i}$ coupling of endogenous chemokine receptors $[41,47]$. For instance the ORF74 (open reading frame 74) 7TM receptor encoded by HHV8 (human herpesvirus 8) associates with both $\mathrm{G}_{\alpha i}$ and $\mathrm{G}_{\alpha q}$ [63] as well as signals through MAP kinases [64] leading to the activation of numerous transcription factors, cell proliferation and transformation, VEGF secretion and angiogenesis [64-68]. The ORF74 from herpesvirus saimiri (HVS-ECRF3) also signals through both $\mathrm{G}_{\alpha i}, \mathrm{G}_{\alpha 12 / 13}$, and $\mathrm{G}_{\alpha q}$ in a liganddependent manner, however the constitutive activity of this receptors is constrained to $\mathrm{G}_{\alpha i}$ and $\mathrm{G}_{\alpha 12 / 13}$, but not $\mathrm{G}_{\alpha q}[69$, 70]. A similar broad spectrum and promiscuous signaling is also observed for the US28 (unique short 28) and UL33 (unique long 33) 7TM receptors encoded by HCMV, which signals constitutively through both $\mathrm{G}_{\alpha i}$, and $\mathrm{G}_{\alpha q}$ along with MAP kinases [71-73].

Besides being evolutionary distinct from the endogenous chemokine receptors, the herpesvirus-encoded chemokine receptors cluster in four families (Figure 1): U12/UL33 of HHV6, HHV7, and CMV; U51/UL78 of HHV6, HHV7 and CMV; US27/US28 of CMV; and ORF74 of HHV8 as well as non-human herpesviruses [50]. (UL78 from CMV is evolutionarily conserved with U51 from HHV6 and HHV7. However, as the UL78 receptors have shown no functional homology to chemokine receptor, they have been excluded from current review.) The common feature of encoding chemokine receptors throughout the pox- and herpesviruses suggests that these receptors play an important role in the viral life cycle as well as in circumvention of the host immune system. A few studies of receptor-disrupted viruses have shown diminished replication in vivo in selected tissues [74, 75].

Chemokine receptors are also found in the genomes of poxviruses $[76,77]$. In contrast to the broader subfamily resemblance to CC as well as CXC chemokine receptors along with the promiscuous chemokine-binding profile of many herpesvirus-encoded receptors, the poxvirus-encoded receptors solely resemble the CCR8 chemokine receptor (as illustrated in Figure 1) and only interact with CCR8-binding ligands $[78,79]$. Briefly, the poxvirus-encoded receptors are located in two areas in the viral genome: $7 \mathrm{~L}$ and $145 \mathrm{R}$. The best characterized poxvirus receptors are $7 \mathrm{~L}$ and $145 \mathrm{R}$ from YLDV (Yaba-like disease virus) [76, 77].

Also, nonchemokine receptors are found in viral genomes exemplified by the BILF family from several $\gamma 1$ herpesviruses including human EBV (Epstein Barr virus). The BILF1 receptors from human and rhesus EBV are the only BILF receptors that have been characterized from a pharmacological point of view and like most other virusencoded 7TM receptors they display constitutive activity $[80,81]$. As an extra refinement and interplay with the host immune system, it should be mentioned that viruses also regulate the expression of endogenous 7TM receptors within the chemokine system, and class A in general. For instance, GPR183, also known as EBI2 (Epstein-Barr virus induced receptor 2), which is induced $>200$ fold upon EBV cell-entry $[33,40,82]$.

\section{The Impact of the DRY-Motif among Endogenous Class A Receptors}

The Asp, Arg, Tyr, or DRY-motif in the intracellular end of TM3 is one of the most conserved motifs among class A 7TM receptors [31] (Figure 2(c)) and plays a pivotal role in receptor activation. This amino acid triplet is located in positions III:25 (3.49), III:26 (3.50), and III:27 (3.51), respectively, at the border to the intracellular loop 2 (ICL2) with a conservation as DRY in $66 \%, 96 \%$, and $67 \%$ of all class A 7TM receptors [31]. The DRY-motif is even more conserved within the chemokine subfamily (Figure 2(a)) with 100\% conservation of ArgIII:26 (3.50) and $95 \%$ conservation of both aromatic residues in position III:27 (3.51) and negatively charged residues in position III:25 (3.49).

As mentioned in the introduction, it has been suggested that, in some class A 7TM receptors (e.g., the $\beta$ adrenergic receptors and in rhodopsin) the ArgIII:26 (3.50) together with AspIII:25 (3.49) and GluVI:-05 (6.30), the latter located in ICL3, form an ionic lock holding TM3 


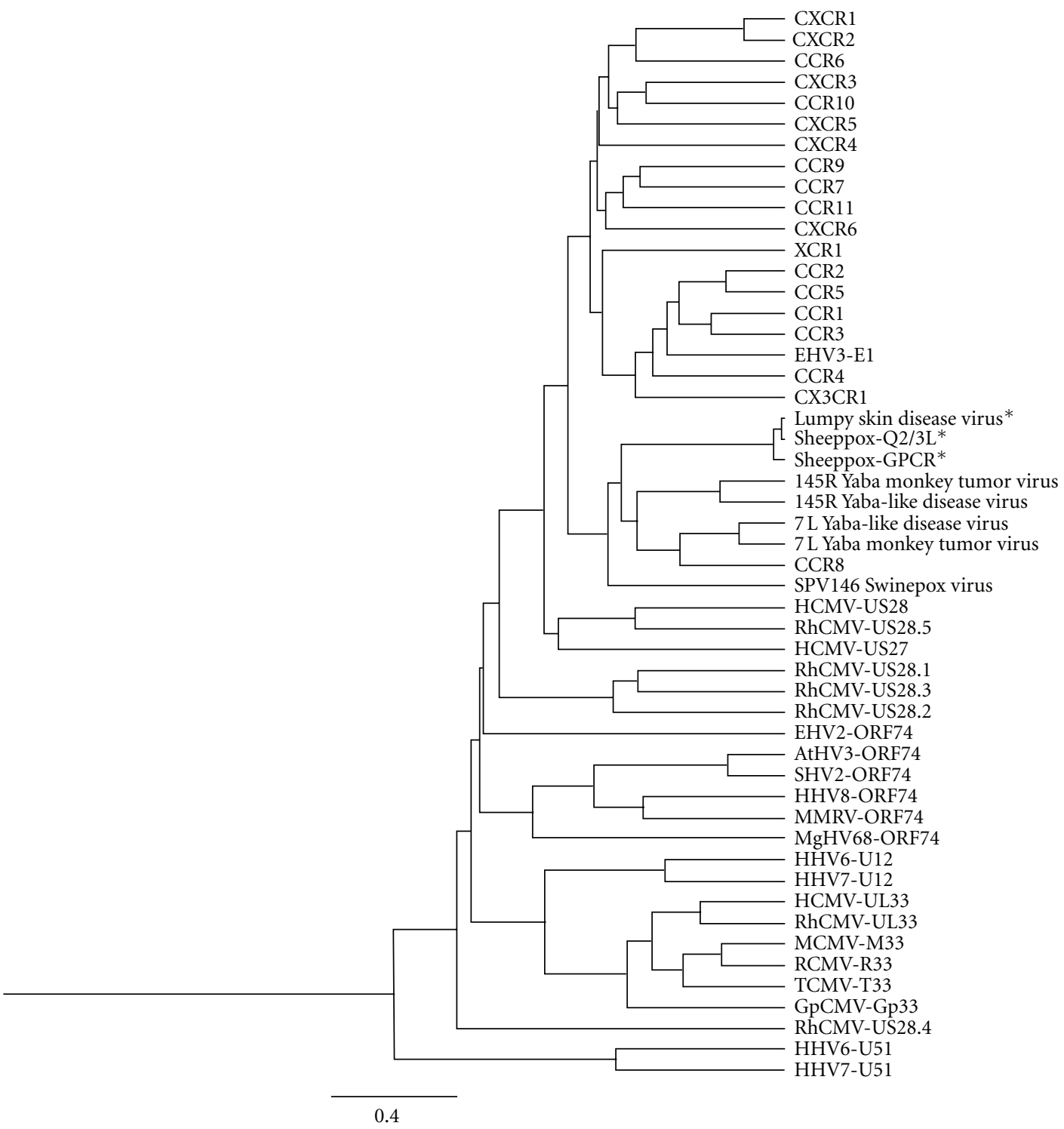

Figure 1: Phylogenetic tree of viral and human chemokine receptors based on their amino acid sequence. The length of each branch reflects the similarity between receptors. It was generated by aligning the sequences using the settings: Blosum62, gap open penalty of 5 and gap extension penalty of 0.1 followed by the Jukes-Cantor distance analysis done in Geneious Pro. For further information about the virusencoded receptors and GenBank accession number please see Table 1. * As the sequence of these viral receptors are very alike it cannot be excluded that they are in fact the same.

and TM6 together in the inactive state [10,36]. During receptor activation, protonation of AspIII:25 (3.49) leads to release of the constraining interaction, thus allowing the outward movement of TM6 $[5,83]$. This is also supported by charged- neutralizing mutations of AspIII:25 (3.49) suggesting that this residue is important for receptor activation [84]. However, the negatively charged residue at position VI:-05 (6.30) is not nearly as conserved as the DRY-motif indicating other possible ways to constrain the receptor in the inactive conformation [30]. During receptor activation, the interaction between adjacent Asp/GluIII:25 (3.49) and ArgIII:26 (3.50) of the DRY-motif is disturbed and ArgIII:26 (3.50) is instead able to interact with TyrV:24 (5.58) as well as directly with the $G_{\alpha}$ protein. This direct interaction with the $G$ protein has been confirmed by the crystal structure of Opsin in complex with a small peptide from the C-terminal of the $\mathrm{G}_{\alpha t}$ protein [21]. Receptor activation opens a pocket at the intracellular site making the interaction with the Cterminal of the $G_{\alpha}$ protein possible. This allows for the exchange of GDP with GTP thus activating the G protein for further downstream signaling [85].

From the crystal structure of the chemokine receptor CXCR4, it is evident that the overall structure is similar to the other crystal structures of class A 7TM receptors, nevertheless with a few differences mainly in the extracellular part which constitutes the chemokine ligand-recognition 


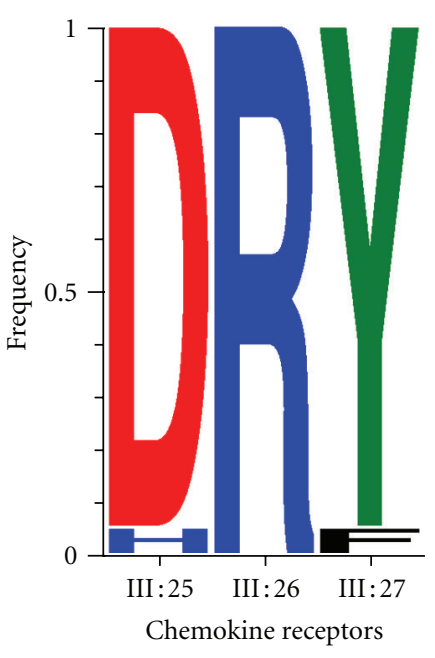

(a)

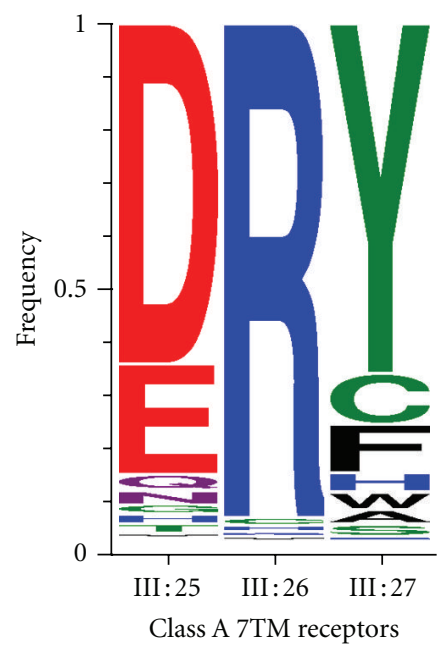

(c)

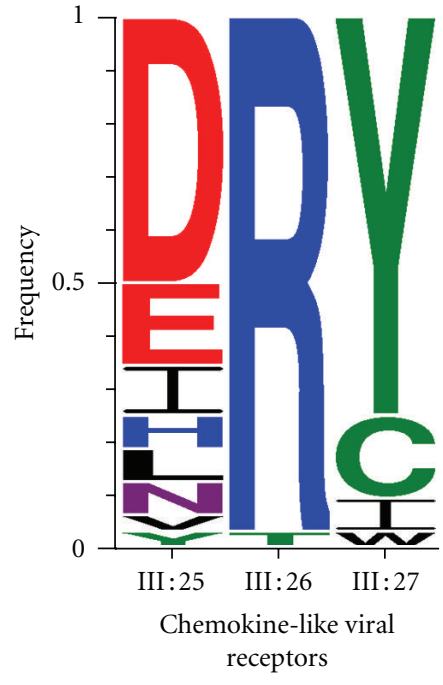

(b)

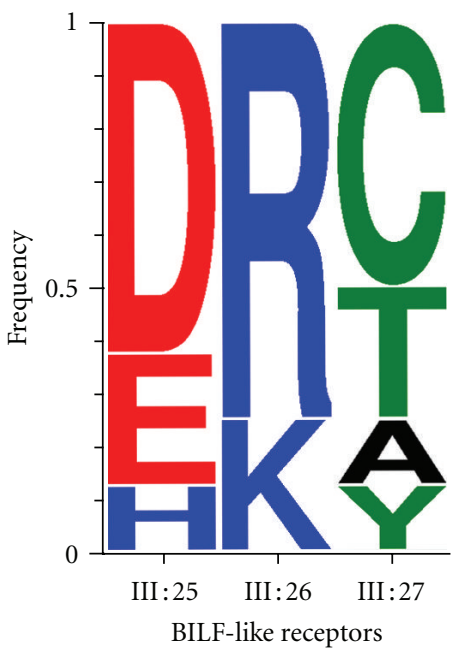

(d)

FIGURE 2: Sequence logos of the DRY-motif for chemokine receptors (a), chemokine-like viral receptors (b), class A 7TM receptors (c), and BILF-like receptors (d). The chemical properties of the amino acids are represented in color (polar: green, neutral: purple, basic: blue, acidic: red, and hydrophobic: black). This figure was created using the web application: http://weblogo.threeplusone.com/.

domain [27]. Importantly, the chemokine receptors (though belonging to class A) contain a positively charged residue at position VI:-05 (6.30) and hence the ionic lock between ArgIII:26 (3.50) and a negative charged residue at VI:-05 (6.30) does not exist in these receptors [38]. The lack of a negative charge in this position has inspired the introduction of the ionic lock in the chemokine receptors by substitution of the positive charge in VI:-05 (6.30) with a negative charge. This introduction of the putatively correct conditions for the ionic lock resulted in a reduced basal activity of the chemokine receptor CCR5, indicating that the receptor is locked in an inactive conformation with no ligandinduced activation and a strongly impaired ability to bind chemokines. Substitution of ArgIII:26 (3.50) with Ala or Gln maintained chemokine binding though still showed reduced basal activity [38]. Thus, the presence of an ionic lock between TM3 and TM6 leaves the chemokine receptor unable to switch to an active conformation; therefore, chemokine receptors must utilize a different mechanism than the classic ionic lock described above. However, the decrease in basal activity of CCR5 upon introduction of the ionic lock is in accordance with the general interpretation of the role of this motif in class A receptor activation, where loss of the ionic lock (VI:-05 (6.30) mutation), leads to constitutive activity [36]. Disregarding the lack of an ionic lock in chemokine receptors, the DRY-motif still plays an important role in the receptor activation, as exemplified in CCR5, where mutation of ArgIII:26 (3.50) to the neutral Asn disrupted both basal activity and chemokine-induced $\mathrm{G}_{\alpha i}$ protein coupling (through calcium mobilization and GTP $\gamma \mathrm{S}$ binding assays) despite retained affinity for CCL4 [86]. Interestingly, an increased basal phosphorylation of 
TABLE 1

\begin{tabular}{|c|c|c|}
\hline No. & Receptor & Accession number \\
\hline 1 & Class A 7TM receptors & \\
\hline 2 & CCR 1 & NP_001286.1 \\
\hline 3 & CCR2 & NP_001116513.2 \\
\hline 4 & CCR3 & NP_001828.1 \\
\hline 5 & CCR4 & NP_005499.1 \\
\hline 6 & CCR5 & NP_000570.1 \\
\hline 7 & CCR6 & NP_004358.2 \\
\hline 8 & CCR7 & NP_001829.1 \\
\hline 9 & CCR8 & NP_005192.1 \\
\hline 10 & CCR9 & NP_112477.1 \\
\hline 11 & CCR10 & NP_057686.2 \\
\hline 12 & CCR11 & NP_057641.1 \\
\hline 13 & CXCR1 & NP_000625.1 \\
\hline 14 & CXCR2 & NP_001548.1 \\
\hline 15 & CXCR3 & NP_001495.1 \\
\hline 16 & CXCR4 & NP_003458.1 \\
\hline 17 & CXCR5 & NP_001707.1 \\
\hline 18 & CXCR6 & NP_006555.1 \\
\hline 19 & CX3CR1 & NP_001328.1 \\
\hline 20 & XCR1 & NP_005274.1 \\
\hline 21 & HCMVUS28 & P69332.1 \\
\hline 22 & RhCMVUS28.1 & YP_068305.1 \\
\hline 23 & RhCMVUS28.2 & AAN15199.1 \\
\hline 24 & RhCMVUS28.3 & YP_068303.1 \\
\hline 25 & RhCMVUS28.4 & YP_068302.1 \\
\hline 26 & RhCMVUS28.5 & YP_068307.1 \\
\hline 27 & HCMVUS27 & P09703.1 \\
\hline 28 & HCMVUL33 & CAA37385.1 \\
\hline 29 & GpCMVGp33 & AAK43591.1 \\
\hline 30 & RhCMVUL33 & YP_068150.1 \\
\hline 31 & TCMVT33 & NP_116383.1 \\
\hline 32 & MCMVM33 & Q83207.1 \\
\hline 33 & RCMVR33 & NP_064138.1 \\
\hline 34 & HHV6U12 & P52380.1 \\
\hline 35 & HHV7U12 & P52381.1 \\
\hline 36 & HHV6U51 & NP_042944.1 \\
\hline 37 & HHV7U51 & YP_073791.1 \\
\hline 38 & HHV8ORF74 & AAC28486.1 \\
\hline 39 & MgHV68ORF74 & NP_044914.1 \\
\hline 40 & AtHV3ORF74 & NP_048046.1 \\
\hline 41 & SHV2ORF74 & NP_040276.1 \\
\hline 42 & MMRVORF74 & NP_570822.1 \\
\hline 43 & EHV2ORF74 & NP_042670.1 \\
\hline 44 & EHV3E1 & NP_042597.1 \\
\hline 45 & SPV 146 Swinepox virus & NP_570306.1 \\
\hline 46 & Sheeppox-GPCR & NP_659585.1 \\
\hline 47 & lumpy skin disease virus & AAN02735.1 \\
\hline 48 & Sheeppox-Q2/3L & Q86917.1 \\
\hline 49 & 7L Yaba-like disease virus & NP_073392.1 \\
\hline 50 & 7L Yaba Monkey Tumor virus & NP_938268.1 \\
\hline 51 & 145R-Yaba Monkey Tumor virus & NP_938396.1 \\
\hline 52 & 145R-Yaba-like disease virus & NP_073530.1 \\
\hline
\end{tabular}

the ArgIII:26Asn- (3.50-) mutated receptor was observed along with $\beta$-arrestin-mediated endocytosis as well as a higher rate of internalization in response to CCL4 stimulation [86]. Other studies have indicated the need for an intact DRY-motif in $\beta$-arrestin1 binding to CCR5, thus supporting the importance of this motif for receptor function [87].

Another class A receptor lacking the ionic lock residue VI:-05 (6.30) is the histamine 4 receptor (H4R), which shows high constitutive activity. Introduction of GluVI:-05 (6.30) did, however, not decrease the constitutive activity [88] as expected from other studies where disruption of an already existing ionic lock leads to increased constitutive activity [36] or like the CCR5 chemokine receptor loss of activity upon ionic lock introduction [38]. Additionally, the H3R also shows constitutive activity in spite of having the putative conditions for an ionic lock [88-90] indicating that the histamine receptors have a functional difference from the general class A 7TM receptors when it comes to activation and constitutive activity. However, the H4R did show complete loss of $\mathrm{G}$ protein activation upon mutation of ArgIII:26 (3.50) supporting the importance of the DRY-motif for coupling to $G$ proteins $[85,88,91]$. A similar phenomenon was observed in the H2R where charge-neutralizing mutations of ArgIII:26 (3.50) led to severely decreased basal cAMP production in terms of efficacy indicating diminished $\mathrm{G}_{\alpha s}$ coupling. However, the mutated receptor was able to induce a response upon agonist stimulation though still with lower efficacy compared to wild type [92]. In the same study, it was shown that the charge-neutralizing mutations of ArgIII:26 also resulted in highly structurally instable receptors, where surface expression could only be detected after stabilization with either an agonist or inverse agonist, indicating a role not only in receptor activation, but also in receptor stability for this position [92]. Furthermore, the DRY-motif has also been implicated in receptor stability of the $\beta 2$-adrenergic receptor [15].

The C5A binding protein, C5L2, is among the few 7TM receptors that lack a positive charge in position III:26, as it has a Leu in this position (together with Asp in III:25 (3.49) and Cys in III:27 (3.51) [93]). The native C5L2 is also known as a nonsignaling C5A binding protein, however, this impaired $\mathrm{G}$ protein coupling could be partially restored by reintroducing ArgIII:26 (3.50) [93]. Other endogenous class A receptors without a positive charge in III:26 (3.50) include D6 and Duffy antigen/receptor for chemokines (DARC) two nonsignaling 7TM structured receptors belonging to the chemokine receptor system. Both are known as nonsignaling proteins as they do not couple to $G$ proteins, but they exert chemokine scavenging and transendothelial transport instead. DARC is, furthermore, rather specifically expressed by endothelial cells lining postcapillary venules, and here it exerts its presumed role in accumulation of extravascular chemokines, chemokine transcytosis, and presentation on the luminal surface thereby facilitating leukocyte adhesion [94-97]. GPR77, GPR78, and GPR133 constitute three orphan class A receptors with unknown functions that also lack the ArgIII:26 (3.50), and, in addition a handful of receptors without positive, charge are identified among the olfactory receptors. 


\section{The DRY-Motif Is Less Conserved among Virus-Encoded 7TM Receptors}

The conservation of the ArgIII:26 (3.50) in the DRY-motif is low among the virally encoded chemokine receptors when compared to the endogenous counterparts (Figures 2(a) and 2(b)). Furthermore, there is a much larger diversity with respect to all three residues as evident by Figure 2(b). These changes in the DRY-motif could be part of the reason for the altered signaling properties with higher constitutive activity, and activation of a broader range of signaling pathways $[53,98]$.

Regarding ArgIII:26 (3.50), one receptor deserves special notice, namely, the CXC chemokine receptor ORF74 from equine herpesvirus 2 (EHV2). This receptor contains a DTW-motif instead of the DRY consensus, thus missing a positive charged residue in position III:26 (3.50). In spite of this, the receptor shows constitutive activity through the $\mathrm{G}_{\alpha i}$ pathway and ligand-mediated signaling in response to the endogenous chemokine CXCL6 [55, 99]. Interestingly, introduction of the DRY-motif in the EHV2-ORF74 led to a 4 -fold decrease in constitutive activity while retaining activation by the agonist, CXCL6 [55], suggesting that this receptor has been optimized to act in the absence of a positive charge in the DRY-motif.

As is also evident from Figure 2(b), the virus-encoded chemokine receptors from different pox- and herpesviruses show a larger diversity in the whole DRY-motif; primarily with large deviations within the first residue III:25 (3.49). For instance, the CXC chemokine receptor ORF74 by HHV8 contains a VRY-motif in place of the endogenous DRYmotif. This receptor is associated with Kaposi's sarcoma and shows a high degree of constitutive signaling and stimulates proliferation [100] as well as tumor transformation in mice [64]. The closest endogenous chemokine receptor to HHV8ORF74 is CXCR2, and studies have shown that replacement of AspIII:25 (3.49) with Val in CXCR2, thus making this receptor more ORF74-like with respect to this motif, leads to constitutive activation of CXCR2 with altered signaling properties in the direction of HHV8-ORF74 signaling [101]. In contrast, the opposite mutation in HHV8-ORF74 (ValIII:25Asp thereby reintroducing the DRY-motif) did not have major effects on either ligand binding or receptor signaling [102]. Another example is the ORF74 receptor from murine herpesvirus 68 (MHV68), which contains an HRCmotif and has been indicated to activate similar oncogenic pathways as HHV8-ORF74 [103, 104]. However, further studies are needed to determine the signaling capabilities of several ORF74 receptors as well as the influence of their altered DRY-motif on constitutive activity and regulatory circumvention.

The human herpesviruses HHV6 and HHV7 both encode two 7TM receptors, U12 and U51, which contain IRY- and ERI-motifs, respectively. HHV6-U12 has been shown to act as a chemokine receptor [105], whereas HHV6$\mathrm{U} 51$ has been shown to be a constitutively active $\mathrm{G}_{\alpha q}$-coupled CC chemokine receptor [106]. However, neither of these two receptors have the functional impact of the altered DRYmotif been studied.
The UL33 family, consisting of 7TM receptors from murine (M33), rat (R33), and human (UL33) cytomegalovirus, is known to constitutively signal through a vast array of $G$ proteins [72]. The rodent counterparts differ from the human by containing an NRY-motif whereas UL33 contains the conserved DRY-motif. A mutational analysis of M33 revealed that ArgIII:26 (3.50) is important for the viral constitutive signaling in NFAT, CREB, and IP-turnover assays as mutation into a neutral Gln abolished constitutive activation of the receptor. The importance of this was supported by in vivo data where a virus with a missing ArgIII:26 (3.50), NRY changed to NQY, was unable to replicate in the salivary glands [107]. Very interestingly, mutation of AsnIII:25 (3.49) into the consensus AspIII:25 (3.49), NRY to DRY, leads to an increased constitutive signaling (especially through NFAT-mediated transcription) suggesting that the endogenous DRY-motif is preferable for high activity. Having lower receptor activity could be advantageous for the virus as this might be favorable for the virus life cycle [107]. In line with the results for M33, a mutation of ArgIII:26 (3.50) rendered the R33 receptor inactive with respect to G protein coupling [108]. However, in contrast to M33, it was found that replacement of AsnIII:25 (3.49) with the endogenous AspIII:25 (3.49) in R33 (NRY to DRY) did not change the constitutive activity, and that replacement with the nonpolar AlaIII:25 (3.49) (NRY to ARY) led to a diminished PLC stimulation, but an unaltered pertussis toxin-sensitive signaling indicating impaired $\mathrm{G}_{\alpha q}$-signaling but maintained $\mathrm{G}_{\alpha i}$.

Another HCMV-encoded receptor, US28, signals constitutively through several pathways such as $\mathrm{G}_{\alpha q}$ /phospholipase $\mathrm{C}, \mathrm{NF} \kappa \mathrm{B}, \mathrm{CREB}$, and MAP kinases [73, 109, 110]. This viral chemokine receptor contains the conserved DRYmotif and a mutational analysis of ArgIII:26Ala found that disruption of the DRY-motif leads to impaired $\mathrm{G}_{\alpha q}$ protein activation and IP-turnover in spite of wild-type levels of cell-surface expression [111]. Like HHV8-ORF74, US28 has been implicated in cancer as the constitutive signaling of the receptor can activate proliferative pathways leading to tumor formation [112-114]. Additionally, HCMV has been found in glioblastomas, which could indicate a possible role in tumorigenesis [115-118].

Also among the BILF receptors, found in several $\gamma 1$ herpesviruses, has this motif obtained extra attention. Interestingly, the DRY-motif in the constitutively active BILF1 receptors from human and rhesus EBV differs from the consensus in all three residues being EKT (GluIII:25 (3.49), LysIII:26 (3.50), ThrIII:27 (3.51), Figure 2(d)) [80, 81]. Substitution of EKT with EAT in BILF1 from EBV resulted in abolished $\mathrm{G}_{\alpha i}$ signaling, whereas the conservative substitution of Lys with Arg (ERT) signaled as wt BILF1 (EKT). Interestingly, introduction of the whole conserved motif (DRY) actually impaired the receptor activity partially, indicating that the EKT-motif is functionally superior to the conserved DRY-motif in this BILF1 receptor. In addition to the $\mathrm{G}_{\alpha i}$ coupling, the authors tested the impact of the EATmotif in NIH3T3 cell transformation and tumor growth in nude mice, and they found that also via these pathways the EAT-motif was completely silent compared to wt BILF1 


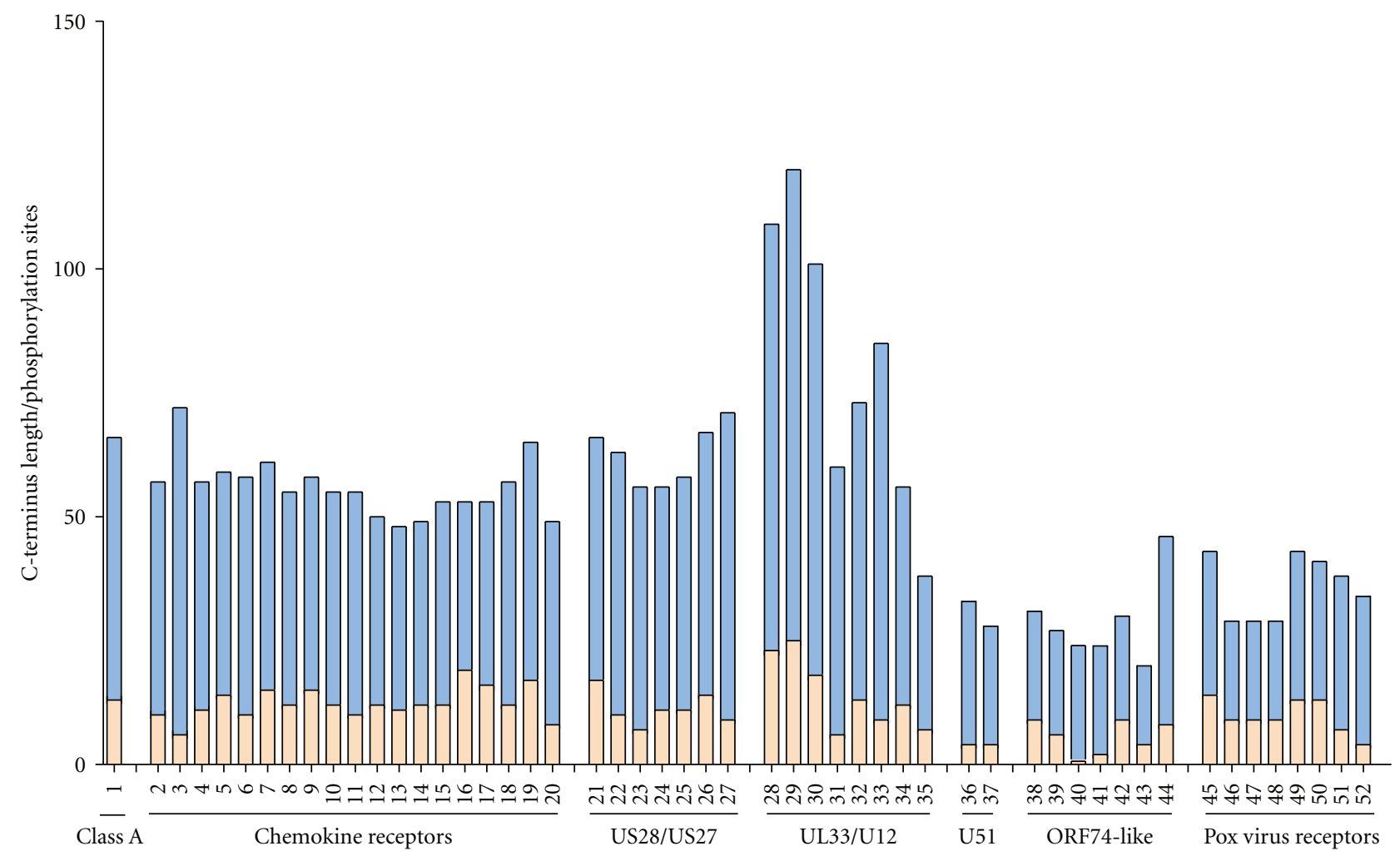

FIGURE 3: Relative sequence length and putative phosphorylation sites of the C-terminal region of class A 7TM receptors, chemokine receptors and virus-encoded chemokine receptors. The vertical axis displays the number of amino acids of the C-terminus (blue), defined as being after the highly conserved proline of the NPxxY-motif, and the number of serine, threonine and tyrosine in this region (beige). The horizontal axis displays the average of 334 non-olfactory class A 7TM receptors (1), the chemokine receptors (2-20) and the viral chemokine receptors (21-52). For further information about specific receptors and GenBank accession number please see Table 1.

(EKT). Furthermore, the DRY substitution displayed an intermediate active phenotype in these two functional readouts [119]. Thus, the BILF1 receptor depends on a positive charge in the DRY-motif and has, as a consequence of the altered motif (DRY to EKT), been optimized to signal with higher activity $[80,81,119]$.

\section{The C-Terminal Tails of Class A Receptors Are Conserved with Respect to Length and Number of Phosphorylation Sites}

Whereas the extracellular N-terminal region of class A 7TM receptors are quite diverse, the intracellular $\mathrm{C}$-terminal tails are more homologous, both in terms of length and primary structure. As evident from Figure 3, the average length and number of phosphorylation sites are similar among the endogenous chemokine receptors and class A 7TM receptors in general, whereas the virally encoded receptors show a larger diversity, but are generally shorter in length and have fewer phosphorylation sites. The phosphorylation sites serve important regulatory purposes for receptor desensitization and cell surface expression [120, 121]. Quickly after receptor activation and $\mathrm{G}$ protein interaction, GRKs initiate phosphorylation of serine and threonine residues in the Cterminal tail (and intracellular loops) thereby promoting the interaction of the receptor with $\beta$-arrestins and a subsequent steric hindering of the receptor/G protein-interaction [4]. The consequences of $\beta$-arrestin recruitment are endocytosis of the receptor/ $\beta$-arrestin complex and a subsequent recycling to the cell surface or degradation. Interestingly, $\beta$ arrestins only associate with the ubiquitin ligase promoting the degradation pathway when it interacts with a ligandstimulated receptor $[122,123]$. The shorter C-terminal tails of the viral receptors could suggest that viruses circumvent the host regulatory processes of receptor internalization in order to obtain constitutive signaling abilities. Furthermore, some viral receptors are constitutively endocytosed and predominantly intracellularly localized [74, 124, 125], which have led to the suggestion, that they could act as scavengers (like DARC and D6 among endogenous chemokine receptors, see above) by internalizing the endogenous chemokine ligands that binds to the receptor and thereby removing the chemokines from the host cell surroundings as a way of evading the immune system, as discussed further below for the HCMV-encoded US28 [53, 124, 126, 127].

\section{The C-Terminal Tail of Endogenous Chemokine Receptors}

The endogenous chemokine receptors are rather similar in their C-terminal tails, and not different from the superfamily of endogenous class A 7TM receptors (Figure 3). 
The 19 human chemokine receptors have in average the same number of phosphorylation sites as the endogenous class A 7TM receptors (13 in each case), and an average length of 57 residues, which is in the proximity of the 66 residues in average for the endogenous class A receptors. The internalization routes and regulation has been described for several endogenous chemokine receptors, an interest facilitated by the discovery of CCR 5 and CXCR 4 acting as HIV cell-entry cofactors $[125,128,129]$. Consequently, the endocytosis pattern of CCR5 and CXCR4 and the regulation of this have been studied in great detail and it was recently shown that internalization of CXCR4 plays an important antiviral role [130-133]. In the case of CCR5, the binding of CCL5 leads to receptor phosphorylation of serine residues in the C-terminal tail by GRKs, which consequently leads to internalization and desensitization of the signal $[134,135]$. Besides the involvement of the serine residues in $\beta$-arrestin recruitment, a dileucine motif in the $\mathrm{C}$-terminal tail is also important for CCR5 receptor endocytosis [136]. Serial truncation of the CCR5 C-terminal tail resulted in progressive loss of cell surface expression, which could not be rescued by substitution with the C-terminal tail of CXCR4 [137]. Mutational analysis of CXCR4 showed that this receptor is likewise dependent on C-terminal serine phosphorylation sites and a dileucine motif for proper receptor internalization $[138,139]$. Internalization of CXCR4 can follow two distinct pathways: CXCL12 ligand-mediated endocytosis was shown to be dependent on the serine phosphorylation sites whereas phorbol ester induced internalization is dependent on the dileucine motif $[131,132]$. Interestingly, a naturally occurring mutation of CXCR4 with C-terminal deletions exists in patients with WHIM syndrome (warts, hypogammaglobulinemia, recurrent bacterial infection, myelokathexis). Loss of the C-terminal tail leads to decreased endocytosis of the receptor and consequently a reduced regulation of the receptor followed by an increased signaling with enhanced calcium flux and cell migration; a possible cause of the pathophysiology seen in WHIM syndrome [140]. Thus, the C-terminal tail plays an important role in the physiology of endogenous chemokine receptors.

\section{The C-Terminal Tails of Virus-Encoded Receptors Are Generally Shorter}

The HCMV-encoded chemokine receptor US28 signals constitutively via several pathways and upon stimulation by CC chemokines [54, 73]. Furthermore, CX3CL1 has been reported to act as an inverse agonist, albeit with low efficacy (up to $25 \%$ inhibition of basal activity) [141]. Additionally, unlike the majority of endogenous class A 7TM receptors, US28 is constitutively internalized in a ligand-independent manner [126, 127, 142]. Thus, by immunofluorescence staining, US28 was found to be accumulated intracellularly in endocytic organelles and by advanced immunogold electron microscopy shown to be localized to multivesicular endosomes [126]. Further studies revealed that US28 endocytosis occurs via a clathrin-mediated mechanism [127]. Importantly, only a small fraction of US28 is present at the cell surface $(<20 \%)$, with the rest undergoing constitutive ligand-independent endocytosis with a fast internalization rate, as compared to CXCR4. Truncation of the C-terminal tail of US28 led to an increase in both magnitude and duration of the constitutive signaling indicating that the C-terminal tail plays a regulatory role in desensitizing the receptor. This was supported by hyperactivation of US28 in cells where $\beta$-arrestin 1 and 2 were genetically deleted [141]. A mutational analysis of serine residues in the $\mathrm{C}$-terminal of US28 revealed that a decreased number of phosphorylation sites increased the cell surface expression of the receptor [143]. Truncating the C-terminal tail of US28 or replacing it with tails from other 7TM receptors (HHV8-ORF74 and human tachykinin NK1) led to an increase in constitutive activity of the receptor. Substitution of the HHV8-ORF74 tail with the tail from US28 diminished the cell surface expression of the HHV8-ORF74 chimera indicating that the C-terminal tail, in itself, is sufficient for desensitization by receptor endocytosis [144]. The constitutive endocytosis of US28 may serve as a chemokine scavenger and mediate the viral immune evasion by antagonizing the recruitment of cells involved in the immune response and thereby manipulating the host immune system. Another HCMVencoded chemokine receptor, US27, also shows a large degree of intracellular localization. Swapping the C-terminal tail of US27 with that of the endogenous chemokine receptor CXCR3 led to cell surface expression similar to wild-type CXCR3; likewise, when substituting the endogenous tail with the viral US27 tail, the chimeric receptor was predominantly located intracellularly indicating that the C-terminal tail of US27 is necessary and sufficient for intracellular localization [145].

In general, the viral chemokine receptors, ORF74, encoded by several herpesviruses have very short C-terminal tails when compared to the endogenous receptors (Figure 3). A study of several $\gamma$-herpesviruses identified an eight-aminoacid conserved region at the membrane proximal part of the $\mathrm{C}$-terminal tail suggested to play a role in $\mathrm{G}$ protein coupling and $\mathrm{G}_{\alpha}$-selectivity [146]. Especially one basic residue showed importance for $\mathrm{G}_{\alpha q}$ coupling - a residue which is conserved among the endogenous chemokine receptors suggesting an evolutionary conserved function of this residue such as G protein signaling [146]. HHV8-ORF74 is primarily located at the cell surface and deletion of the five terminal amino acids containing 3 phosphorylation sites did not seem to affect cell surface expression, though it did impact the signaling capabilities of the receptor seen by a diminished NF $\kappa B$ and AP-1 signaling [147]. As signaling deficiencies are seen by the removal of just five amino acids, it is tempting to consider that the length of the C-terminal tail has been optimized to only contain necessities and thus demonstrating a minimum requirement for a functional viral receptor tail. Another study also found expression levels of 12 and 24 amino acids C-terminal tail deletions similar to wild-type albeit with reduced constitutive activity in spite of retained ligand regulation by chemokines [148]. It was suggested that the Cterminal helix 8 , which is present in the terminal 24 amino acids, is involved in stabilizing the interaction between the receptor and $G$ protein, thus playing a role in mediating 
TABLE 2

\begin{tabular}{lcc}
\hline No. & Receptor & Accession number \\
\hline 1 & Class A 7TM receptors & \\
2 & CaHV3-ORF6 & NP_733858.1 \\
3 & CHV15-BILF1-rh & YP_068006.1 \\
4 & EBV-BILF1 & YP_401711.1 \\
5 & EHV2-E6 & NP_042607.1 \\
6 & AlceHV-E5 & NP_065513.1 \\
7 & PLHV3-A5 & AAO12316.1 \\
8 & PHV2-A5 & AAF16523.1 \\
9 & PLHV1-A5 & AAF16521.1 \\
\hline
\end{tabular}

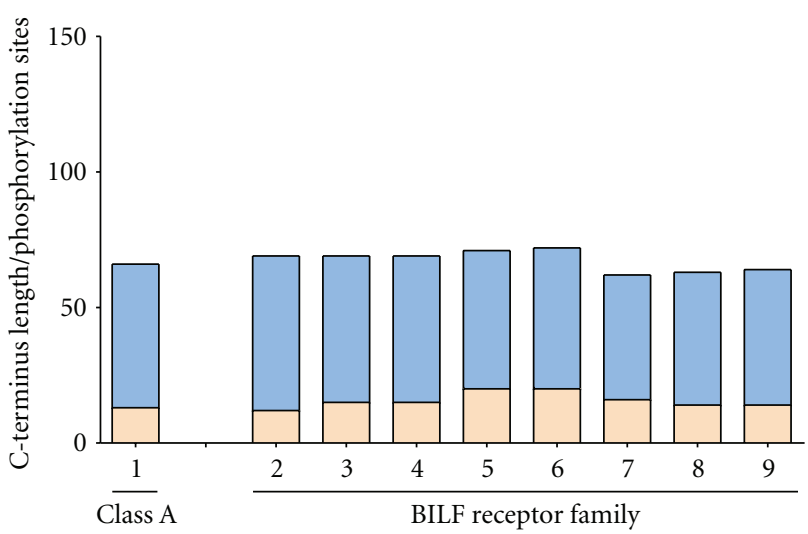

FIGURE 4: Relative sequence length and putative phosphorylation sites of the C-terminal region of class A 7TM receptors and the BILF-like receptors. The vertical axis displays the number of amino acids of the C-terminus (blue), defined as being after the highly conserved proline of the NPxxY-motif (class A 7TM receptors) or predicted by the Transmembrane Hidden Markov model using Geneious Pro (BILF receptor family), and the number of serine, threonine, and tyrosine in this region (beige). The horizontal axis displays the average of 334 non-olfactory class A 7TM receptors (1) and the EBV-encoded BILF receptors (2-9). For further details about specific receptors and GenBank accession number please see Table 2.

signals upon chemokine binding [148]. Though the Cterminal tail of ORF74 appears to be involved in signal mediation, deletion of small parts of the tail including phosphorylation sites does not seem to largely affect cell surface expression or constitutive signaling suggesting that a short tail is enough for the receptor to function to a certain degree. Having such short tails might be a way of evading host regulatory mechanisms, such as GRKs and internalization, thereby ensuring virus-mediated constitutive signaling.

The BILF receptor family is rather conserved when it comes to the length of their $\mathrm{C}$-terminal tails suggesting that the C-terminus serves an important purpose for the virus (Figure 4). The BILF1 receptor encoded by EBV shows a similar cell surface expression pattern as HHV8-ORF74 and signal constitutively through $G_{\alpha i}[80]$. Though the BILF1 receptor does not resemble the endogenous chemokine receptors, it does serve a purpose in viral immune evasion as it is involved in internalization and degradation of MHCI (major histocompatibility complex class I) molecules. Deletion of the C-terminal tail of the receptor led to impaired lysosomal degradation of internalized MHC-I molecules suggesting that the tail might contain a localization sequence guiding the receptor/MHC-I complex to the lysosomes [149].

\section{Summary}

From what is reviewed above, it is evident that the virus-encoded 7TM receptors differ from the endogenous counterparts - both from a structural and a functional point of view. The viral receptors have been captured from the host and through evolution (i.e., combinatorial chemistry by random mutagenesis followed by natural selection of the most virulent strain) been optimized to benefit the virus life cycle. As the chemokine receptor exploitation (and the general 7TM receptor piracy) is a widespread phenomenon among many viruses, it is likely that these receptors serve important purposes for virus survival, for instance, evasion of the antimicrobial immune response, viral persistence, viral dissemination, and control of own infection as shown for a few receptors. The selection of the chemokine system for interference by the viruses points towards this system as essential in multiple different immune responses. By studying the structural and functional alterations in the virusencoded receptors as compared to the endogenous receptors, greater knowledge can be obtained for 7TM receptors in general. Thus, from a molecular pharmacology point of view, the chemokine receptors represent unique opportunities to study basic principles of receptor activation, internalization, and recycling pathways as examples of targeted evolution where the receptors have undergone major changes driven by a heavy evolutionary pressure. Since 7TM receptors are excellent drug targets, the development of high-potency antagonists or inverse agonists for the virus-encoded 7TM receptors could putatively pave the path for tomorrow's antiviral and anti-inflammatory drugs.

\section{Acknowledgments}

This review was supported by the Lundbeck Foundation, the Novo-Nordisk Foundation, NHMRC grant 631401 and the Faculty of Health Sciences, University of Copenhagen.

\section{References}

[1] D. M. Rosenbaum, S. G. F. Rasmussen, and B. K. Kobilka, "The structure and function of G-protein-coupled receptors," Nature, vol. 459, no. 7245, pp. 356-363, 2009.

[2] K. Rajagopal, R. J. Lefkowitz, and H. A. Rockman, "When 7 transmembrane receptors are not G protein-coupled receptors," Journal of Clinical Investigation, vol. 115, no. 11, pp. 2971-2974, 2005.

[3] T. M. Cabrera-Vera et al., "Insights into G protein structure, function, and regulation," Endocrine Reviews, vol. 24, no. 6, pp. 765-781, 2003. 
[4] R. J. Lefkowitz, "Seven transmembrane receptors: something old, something new," Acta Physiologica, vol. 190, no. 1, pp. 9-19, 2007.

[5] C. Altenbach, A. K. Kusnetzow, O. P. Ernst, K. P. Hofmann, and W. L. Hubbell, "High-resolution distance mapping in rhodopsin reveals the pattern of helix movement due to activation," Proceedings of the National Academy of Sciences of the United States of America, vol. 105, no. 21, pp. 7439-7444, 2008.

[6] W. L. Hubbell, C. Altenbach, C. M. Hubbell, and H. G. Khorana, "Rhodopsin structure, dynamics, and activation: a perspective from crystallography, site-directed spin labeling, sulfhydryl reactivity, and disulfide cross-linking," Advances in Protein Chemistry, vol. 63, pp. 243-290, 2003.

[7] T. W. Schwartz, T. M. Frimurer, B. Holst, M. M. Rosenkilde, and C. E. Elling, "Molecular mechanism of $7 \mathrm{tm}$ receptor activation-a global toggle switch model," Annual Review of Pharmacology and Toxicology, vol. 46, pp. 481-519, 2006.

[8] T. W. Schwartz, "Locating ligand-binding sites in 7tm receptors by protein engineering," Current Opinion in Biotechnology, vol. 5, no. 4, pp. 434-444, 1994.

[9] J. A. Ballesteros and H. Weinstein, "Integrated methods for the construction of three-dimensional models and computational probing of structure-function relations in $\mathrm{G}$ protein-coupled receptors," in Receptor molecular biology, S. C. Sealfon, Ed., Academic Press, New York, NY, USA, 1995.

[10] K. Palczewski, T. Kumasaka, T. Hori et al., "Crystal structure of rhodopsin: a G protein-coupled receptor," Science, vol. 289, no. 5480, pp. 739-745, 2000.

[11] V. Cherezov, D. M. Rosenbaum, M. A. Hanson et al., "Highresolution crystal structure of an engineered human $\beta 2$ adrenergic G protein-coupled receptor," Science, vol. 318, no. 5854, pp. 1258-1265, 2007.

[12] T. Warne et al., "Structure of a betal-adrenergic G-proteincoupled receptor," Nature, no. 7203, pp. 486-491, 2008.

[13] S. G. F. Rasmussen, H. J. Choi, J. J. Fung et al., "Structure of a nanobody-stabilized active state of the $\beta 2$ adrenoceptor," Nature, vol. 469, no. 7329, pp. 175-180, 2011.

[14] S. G. Rasmussen et al., "Crystal structure of the beta 2 adrenergic receptor-Gs protein complex," Nature, vol. 477, no. 7366, pp. 549-555, 2011.

[15] S. G. Rasmussen et al., "Crystal structure of the human beta2 adrenergic G-protein-coupled receptor," Nature, vol. 450, no. 7168, pp. 383-387, 2007.

[16] A. S. Dore et al., "Structure of the adenosine A(2A) receptor in complex with ZM241385 and the xanthines XAC and caffeine," Structure, vol. 19, no. 9, pp. 1283-1293, 2011.

[17] G. Lebon, T. Warne, P. C. Edwards et al., "Agonist-bound adenosine A2A receptor structures reveal common features of GPCR activation," Nature, vol. 474, no. 7352, pp. 521-525, 2011.

[18] F. Xu, H. Wu, V. Katritch et al., "Structure of an agonistbound human A2A adenosine receptor," Science, vol. 332, no. 6027, pp. 322-327, 2011.

[19] H. W. Choe, Y. J. Kim, J. H. Park et al., "Crystal structure of metarhodopsin II,” Nature, vol. 471, no. 7340, pp. 651-655, 2011.

[20] J. Standfuss, P. C. Edwards, A. D'Antona et al., "The structural basis of agonist-induced activation in constitutively active rhodopsin," Nature, vol. 471, no. 7340, pp. 656-660, 2011.

[21] P. Scheerer, J. H. Park, P. W. Hildebrand et al., "Crystal structure of opsin in its G-protein-interacting conformation," Nature, vol. 455, no. 7212, pp. 497-502, 2008.
[22] K. Haga, A. C. Kruse, H. Asada et al., "Structure of the human M2 muscarinic acetylcholine receptor bound to an antagonist," Nature, vol. 482, no. 7386, pp. 547-551, 2012.

[23] A. C. Kruse, J. Hu, A. C. Pan et al., "Structure and dynamics of the M3 muscarinic acetylcholine receptor," Nature, vol. 482, no. 7386, pp. 552-556, 2012.

[24] E. Y. T. Chien, W. Liu, Q. Zhao et al., "Structure of the human dopamine D3 receptor in complex with a D2/D3 selective antagonist," Science, vol. 330, no. 6007, pp. 1091-1095, 2010.

[25] M. A. Hanson, C. B. Roth, E. Jo et al., "Crystal structure of a lipid G protein-coupled receptor," Science, vol. 335, no. 6070, pp. 851-855, 2012.

[26] T. Shimamura et al., "Structure of the human histamine H1 receptor complex with doxepin," Nature, vol. 475, no. 7354, pp. 65-70, 2011.

[27] B. Wu, E. Y. T. Chien, C. D. Mol et al., "Structures of the CXCR4 chemokine GPCR with small-molecule and cyclic peptide antagonists," Science, vol. 330, no. 6007, pp. 10661071,2010

[28] J. H. Park, P. Scheerer, K. P. Hofmann, H. W. Choe, and O. P. Ernst, "Crystal structure of the ligand-free G-proteincoupled receptor opsin," Nature, vol. 454, no. 7201, pp. 183187, 2008.

[29] V. P. Jaakola, M. T. Griffith, M. A. Hanson et al., "The 2.6 angstrom crystal structure of a human A2A adenosine receptor bound to an antagonist," Science, vol. 322, no. 5905, pp. 1211-1217, 2008.

[30] R. Nygaard, T. M. Frimurer, B. Holst, M. M. Rosenkilde, and T. W. Schwartz, "Ligand binding and micro-switches in 7tm receptor structures," Trends in Pharmacological Sciences, vol. 30, no. 5, pp. 249-259, 2009.

[31] T. Mirzadegan, G. Benko, S. Filipek, and K. Palczewski, "Sequence analyses of G-protein-coupled receptors: similarities to rhodopsin," Biochemistry, vol. 42, no. 10, pp. 27592767, 2003.

[32] M. M. Rosenkilde, T. Benned-Jensen, T. M. Frimurer, and T. W. Schwartz, "The minor binding pocket: a major player in $7 \mathrm{tm}$ receptor activation," Trends in Pharmacological Sciences, vol. 31, no. 12, pp. 567-574, 2010.

[33] T. Benned-Jensen and M. M. Rosenkilde, "Structural motifs of importance for the constitutive activity of the orphan $7 \mathrm{tm}$ receptor EBI2: analysis of receptor activation in the absence of an agonist," Molecular Pharmacology, vol. 74, no. 4, pp. 1008-1021, 2008.

[34] T. Benned-Jensen and M. M. Rosenkilde, "The role of transmembrane segment II in $7 \mathrm{tm}$ receptor activation," Current Molecular Pharmacology, vol. 2, no. 2, pp. 140-148, 2009.

[35] T. W. Schwartz and T. P. Sakmar, "Structural biology: snapshot of a signalling complex," Nature, vol. 477, no. 7366, pp. 540-541, 2011.

[36] J. A. Ballesteros, A. D. Jensen, G. Liapakis et al., "Activation of the beta 2-adrenergic receptor involves disruption of an ionic lock between the cytoplasmic ends of transmembrane segments 3 and 6," Journal of Biological Chemistry, vol. 276, no. 31, pp. 29171-29177, 2001.

[37] D. M. Rosenbaum, C. Zhang, J. A. Lyons et al., "Structure and function of an irreversible agonist- $\beta 2$ adrenoceptor complex," Nature, vol. 469, no. 7329, pp. 236-240, 2011.

[38] J. Y. Springael, C. de Poorter, X. Deupi, J. Van Durme, L. Pardo, and M. Parmentier, "The activation mechanism of chemokine receptor CCR5 involves common structural changes but a different network of interhelical interactions 
relative to rhodopsin," Cellular Signalling, vol. 19, no. 7, pp. 1446-1456, 2007.

[39] K. N. Nobles, K. Xiao, S. Ahn et al., "Distinct phosphorylation sites on the $\beta_{2}$-adrenergic receptor establish a barcode that encodes differential functions of $\beta$-arrestin," Science Signaling, vol. 4, no. 185, Article ID ra51, 2011.

[40] M. M. Rosenkilde and N. Kledal, "Targeting herpesvirus reliance of the chemokine system," Current Drug Targets, vol. 7, no. 1, pp. 103-118, 2006.

[41] M. M. Rosenkilde, "Virus-encoded chemokine receptorsputative novel antiviral drug targets," Neuropharmacology, vol. 48, no. 1, pp. 1-13, 2005.

[42] P. M. Murphy, "Viral exploitation and subversion of the immune system through chemokine mimicry," Nature Immunology, vol. 2, no. 2, pp. 116-122, 2001.

[43] M. M. Rosenkilde and T. W. Schwartz, "Glu VII:06-a highly conserved and selective anchor point for non-peptide ligands in chemokine receptors," Current Topics in Medicinal Chemistry, vol. 6, no. 13, pp. 1319-1333, 2006.

[44] P. M. Murphy, M. Baggiolini, I. F. Charo et al., "International union of pharmacology. XXII. Nomenclature for chemokine receptors," Pharmacological Reviews, vol. 52, no. 1, pp. 145$176,2000$.

[45] P. M. Murphy, "International union of pharmacology. XXX. Update on chemokine receptor nomenclature," Pharmacological Reviews, vol. 54, no. 2, pp. 227-229, 2002.

[46] R. M. Strieter, P. J. Polverini, S. L. Kunkel et al., "The functional role of the ELR motif in CXC chemokinemediated angiogenesis," Journal of Biological Chemistry, vol. 270, no. 45, pp. 27348-27357, 1995.

[47] M. M. Rosenkilde and T. W. Schwartz, "The chemokine system-a major regulator of angiogenesis in health and disease," APMIS, vol. 112, no. 7-8, pp. 481-495, 2004.

[48] P. J. Holst and M. M. Rosenkilde, "Microbiological exploitation of the chemokine system," Microbes and Infection, vol. 5, no. 2, pp. 179-187, 2003.

[49] E. R. Neptune and H. R. Bourne, "Receptors induce chemotaxis by releasing the $\beta \gamma$ subunit of $\mathrm{Gi}$, not by activating $\mathrm{Gq}$ or Gs," Proceedings of the National Academy of Sciences of the United States of America, vol. 94, no. 26, pp. 14489-14494, 1997.

[50] M. M. Rosenkilde, M. Waldhoer, H. R. Lüttichau, and T. W. Schwartz, "Virally encoded 7tm receptors," Oncogene, vol. 20, no. 13, pp. 1582-1593, 2001.

[51] H. Choe, K. A. Martin, M. Farzan, J. Sodroski, N. P. Gerard, and C. Gerard, "Structural interactions between chemokine receptors, gp120 Env and CD4," Seminars in Immunology, vol. 10, no. 3, pp. 249-257, 1998.

[52] O. Pleskoff, C. Tréboute, A. Brelot, N. Heveker, M. Seman, and M. Alizon, "Identification of a chemokine receptor encoded by human cytomegalovirus as a cofactor for HIV1 entry," Science, vol. 276, no. 5320, pp. 1874-1878, 1997.

[53] M. M. Rosenkilde, M. J. Smit, and M. Waldhoer, "Structure, function and physiological consequences of virally encoded chemokine seven transmembrane receptors," British Journal of Pharmacology, vol. 153, supplement 1, pp. S154-S166, 2008.

[54] M. Waldhoer, T. N. Kledal, H. Farrell, and T. W. Schwartz, "Murine cytomegalovirus (CMV) M33 and human CMV US28 receptors exhibit similar constitutive signaling activities," Journal of Virology, vol. 76, no. 16, pp. 8161-8168, 2002.

[55] M. M. Rosenkilde, T. N. Kledal, and T. W. Schwartz, "High constitutive activity of a virus-encoded seven transmembrane receptor in the absence of the conserved DRY motif (Asp-Arg-Tyr) in transmembrane helix 3," Molecular Pharmacology, vol. 68, no. 1, pp. 11-19, 2005.

[56] M. J. Smit, D. Verzijl, P. Casarosa, M. Navis, H. Timmerman, and R. Leurs, "Kaposi's sarcoma-associated herpesvirusencoded G protein-coupled receptor ORF74 constitutively activates p44/p42 MAPK and Akt via Gi and phospholipase C-dependent signaling pathways," Journal of Virology, vol. 76, no. 4, pp. 1744-1752, 2002.

[57] K. A. McLean, P. J. Holst, L. Martini, T. W. Schwartz, and M. M. Rosenkilde, "Similar activation of signal transduction pathways by the herpesvirus-encoded chemokine receptors US28 and ORF74," Virology, vol. 325, no. 2, pp. 241-251, 2004.

[58] R. Seifert and K. Wenzel-Seifert, "Constitutive activity of Gproteins-coupled receptors: cause of disease and common property of wild-type receptors," Naunyn-Schmiedeberg's Archives of Pharmacology, vol. 366, no. 5, pp. 381-416, 2002.

[59] L. S. Robbins, J. H. Nadeau, K. R. Johnson et al., "Pigmentation phenotypes of variant extension locus alleles result from point mutations that alter MSH receptor function," Cell, vol. 72, no. 6, pp. 827-834, 1993.

[60] S. Srinivasan, C. Lubrano-Berthelier, C. Govaerts et al., "Constitutive activity of the melanocortin-4 receptor is maintained by its $\mathrm{N}$-terminal domain and plays a role in energy homeostasis in humans," Journal of Clinical Investigation, vol. 114, no. 8, pp. 1158-1164, 2004.

[61] J. Pantel, M. Legendre, S. Cabrol et al., "Loss of constitutive activity of the growth hormone secretagogue receptor in familial short stature," Journal of Clinical Investigation, vol. 116, no. 3, pp. 760-768, 2006.

[62] P. R. Robinson, G. B. Cohen, E. A. Zhukovsky, and D. D. Oprian, "Constitutively active mutants of rhodopsin," Neuron, vol. 9, no. 4, pp. 719-725, 1992.

[63] M. M. Rosenkilde, T. N. Kledal, H. Bräuner-Osborne, and T. W. Schwartz, "Agonists and inverse agonists for the herpesvirus 8-encoded constitutively active seventransmembrane oncogene product, ORF-74," Journal of Biological Chemistry, vol. 274, no. 2, pp. 956-961, 1999.

[64] C. Bais, B. Santomasso, O. Coso et al., "G-protein-coupled receptor of Kaposi's sarcoma-associated herpesvirus is a viral oncogene and angiogenesis activator," Nature, vol. 391, no. 6662, pp. 86-89, 1998.

[65] A. Sodhi, S. Montaner, V. Patel et al., "The Kaposi's sarcomaassociated herpes virus $G$ protein-coupled receptor upregulates vascular endothelial growth factor expression and secretion through mitogen-activated protein kinase and p38 pathways acting on hypoxia-inducible factor $1 \alpha$," Cancer Research, vol. 60, no. 17, pp. 4873-4880, 2000.

[66] S. Montaner, A. Sodhi, S. Pece, E. A. Mesri, and J. S. Gutkind, "The Kaposi's sarcoma-associated herpesvirus G proteincoupled receptor promotes endothelial cell survival through the activation of Akt/protein kinase B," Cancer Research, vol. 61, no. 6, pp. 2641-2648, 2001.

[67] S. Montaner, A. Sodhi, A. Molinolo et al., "Endothelial infection with KSHV genes in vivo reveals that vGPCR initiates Kaposi's sarcomagenesis and can promote the tumorigenic potential of viral latent genes," Cancer Cell, vol. 3, no. 1, pp. 23-36, 2003.

[68] A. Sodhi, S. Montaner, V. Patel et al., "Akt plays a central role in sarcomagenesis induced by Kaposi's sarcoma herpesvirusencoded G protein-coupled receptor," Proceedings of the National Academy of Sciences of the United States of America, vol. 101, no. 14, pp. 4821-4826, 2004. 
[69] M. M. Rosenkildel, K. A. McLean, P. J. Holst, and T. W. Schwartz, "The CXC chemokine receptor encoded by herpesvirus saimiri, ECRF3, shows ligand-regulated signaling through $\mathrm{Gi}, \mathrm{Gq}$, and $\mathrm{G} \mathrm{12/13}$ proteins but constitutive signaling only through Gi and G12/13 proteins," Journal of Biological Chemistry, vol. 279, no. 31, pp. 32524-32533, 2004.

[70] S. K. Ahuja and P. M. Murphy, "Molecular piracy of mammalian interleukin-8 receptor type B by herpesvirus saimiri," Journal of Biological Chemistry, vol. 268, no. 28, pp. 2069120694, 1993.

[71] T. N. Kledal, M. M. Rosenkilde, and T. W. Schwartz, "Selective recognition of the membrane-bound $\mathrm{CX} 3 \mathrm{C}$ chemokine, fractalkine, by the human cytomegalovirus-encoded broadspectrum receptor US28," FEBS Letters, vol. 441, no. 2, pp. 209-214, 1998.

[72] P. Casarosa, Y. K. Gruijthuijsen, D. Michel et al., "Constitutive signaling of the human cytomegalovirus-encoded receptor UL33 differs from that of its rat cytomegalovirus homolog R33 by promiscuous activation of $\mathrm{G}$ proteins of the Gq, Gi, and Gs classes," Journal of Biological Chemistry, vol. 278, no. 50, pp. 50010-50023, 2003.

[73] P. Casarosa, R. A. Bakker, D. Verzijl et al., "Constitutive signaling of the human cytomegalovirus-encoded chemokine receptor US28," Journal of Biological Chemistry, vol. 276, no. 2, pp. 1133-1137, 2001.

[74] N. J. Davis-poynter, D. M. Lynch, H. Vally et al., "Identification and characterization of a $\mathrm{G}$ protein-coupled receptor homolog encoded by murine cytomegalovirus," Journal of Virology, vol. 71, no. 2, pp. 1521-1529, 1997.

[75] P. S. Beisser, C. Vink, J. G. van Dam, G. Grauls, S. J. V. Vanherle, and C. A. Bruggeman, "The R33 G protein-coupled receptor gene of rat cytomegalovirus plays an essential role in the pathogenesis of viral infection," Journal of Virology, vol. 72, no. 3, pp. 2352-2363, 1998.

[76] A. Alcami, "Viral mimicry of cytokines, chemokines and their receptors," Nature Reviews Immunology, vol. 3, no. 1, pp. 36-50, 2003.

[77] A. Alcami, "Interaction of viral chemokine inhibitors with chemokines," Methods in Molecular Biology, vol. 239, pp. 167-180, 2004.

[78] P. Najarro, H. J. Lee, J. Fox, J. Pease, and G. L. Smith, "Yabalike disease virus protein $7 \mathrm{~L}$ is a cell-surface receptor for chemokine CCL1," Journal of General Virology, vol. 84, pp. 3325-3336, 2003.

[79] P. Najarro, C. Gubser, M. Hollinshead, J. Fox, J. Pease, and G. L. Smith, "Yaba-like disease virus chemokine receptor 7L, a CCR8 orthologue," Journal of General Virology, vol. 87, pp. 809-816, 2006.

[80] S. J. Paulsen, M. M. Rosenkilde, J. Eugen-Olsen, and T. N. Kledal, "Epstein-barr virus-encoded BILF1 is a constitutively active G protein-coupled receptor," Journal of Virology, vol. 79, no. 1, pp. 536-546, 2005.

[81] P. S. Baisser, D. Verzijl, Y. K. Gruijthuijsen et al., "The Epstein-Barr virus BILF1 gene encodes a G protein-coupled receptor that inhibits phosphorylation of RNA-dependent protein kinase," Journal of Virology, vol. 79, no. 1, pp. 441449, 2005.

[82] M. M. Rosenkilde, T. Benned-Jensen, H. Andersen et al., "Molecular pharmacological phenotyping of EBI2: an orphan seven-transmembrane receptor with constitutive activity," Journal of Biological Chemistry, vol. 281, no. 19, pp. 13199-13208, 2006.
[83] U. Gether, F. Asmar, A. K. Meinild, and S. G. F. Rasmussen, "Structural basis for activation of G-protein-coupled receptors," Pharmacology and Toxicology, vol. 91, no. 6, pp. 304312, 2002.

[84] S. G. F. Rasmussen, A. D. Jensen, G. Liapakis, P. Ghanouni, J. A. Javitch, and U. Gether, "Mutation of a highly conserved aspartic acid in the $\beta 2$ adrenergic receptor: constitutive activation, structural instability, and conformational rearrangement of transmembrane segment 6," Molecular Pharmacology, vol. 56, no. 1, pp. 175-184, 1999.

[85] W. M. Oldham and H. E. Hamm, "Heterotrimeric G protein activation by G-protein-coupled receptors," Nature Reviews Molecular Cell Biology, vol. 9, no. 1, pp. 60-71, 2008.

[86] B. Lagane, S. Ballet, T. Planchenault et al., "Mutation of the DRY motif reveals different structural requirements for the CC chemokine receptor 5-mediated signaling and receptor endocytosis," Molecular Pharmacology, vol. 67, no. 6, pp. 1966-1976, 2005.

[87] F. Hüttenrauch, A. Nitzki, F. T. Lin, S. Höning, and M. Oppermann, " $\beta$-arrestin binding to CC chemokine receptor 5 requires multiple $\mathrm{C}$-terminal receptor phosphorylation sites and involves a conserved Asp-Arg-Tyr sequence motif," Journal of Biological Chemistry, vol. 277, no. 34, pp. 3076930777, 2002.

[88] E. H. Schneider, D. Schnell, A. Strasser, S. Dove, and R. Seifert, "Impact of the DRY motif and the missing "ionic lock" on constitutive activity and G-protein coupling of the human histamine H4 receptor," Journal of Pharmacology and Experimental Therapeutics, vol. 333, no. 2, pp. 382-392, 2010.

[89] K. Takahashi, S. Tokita, and H. Kotani, "Generation and characterization of highly constitutive active histamine $\mathrm{H} 3$ receptors," Journal of Pharmacology and Experimental Therapeutics, vol. 307, no. 1, pp. 213-218, 2003.

[90] A. Rouleau, X. Ligneau, J. Tardivel-Lacombe et al., "Histamine H3-receptor-mediated [35S]GTP $\gamma[\mathrm{S}]$ binding: evidence for constitutive activity of the recombinant and native rat and human $\mathrm{H} 3$ receptors," British Journal of Pharmacology, vol. 135, no. 2, pp. 383-392, 2002.

[91] K. Kristiansen, "Molecular mechanisms of ligand binding, signaling, and regulation within the superfamily of Gprotein-coupled receptors: molecular modeling and mutagenesis approaches to receptor structure and function," Pharmacology and Therapeutics, vol. 103, no. 1, pp. 21-80, 2004.

[92] A. E. Alewijnse, H. Timmerman, E. H. Jacobs et al., "The effect of mutations in the DRY motif on the constitutive activity and structural instability of the histamine $\mathrm{H} 2$ receptor," Molecular Pharmacology, vol. 57, no. 5, pp. 890898, 2000.

[93] S. Okinaga, D. Slattery, A. Humbles et al., "C5L2, a nonsignaling C5A binding protein," Biochemistry, vol. 42, no. 31, pp. 9406-9415, 2003.

[94] S. C. Peiper, Z. X. Wang, K. Neote et al., "The duffy antigen/ receptor for chemokines (DARC) is expressed in endothelial cells of duffy negative individuals who lack the erythrocyte receptor," Journal of Experimental Medicine, vol. 181, no. 4, pp. 1311-1317, 1995.

[95] M. Pruenster and A. Rot, "Throwing light on DARC," Biochemical Society Transactions, vol. 34, pp. 1005-1008, 2006.

[96] R. J. B. Nibbs, S. M. Wylie, J. Yang, N. R. Landau, and G. J. Graham, "Cloning and characterization of a novel 
promiscuous human $\beta$-chemokine receptor D6," Journal of Biological Chemistry, vol. 272, no. 51, pp. 32078-32083, 1997.

[97] M. Weber, E. Blair, C. V. Simpson et al., "The chemokine receptor D6 constitutively traffics to and from the cell surface to internalize and degrade chemokines," Molecular Biology of the Cell, vol. 15, no. 5, pp. 2492-2508, 2004.

[98] P. J. Holst, H. R. Lüttichau, T. W. Schwartz, and M. M. Rosenkilde, "Virally encoded chemokines and chemokine receptors in the role of viral infections," Contributions to Microbiology, vol. 10, pp. 232-252, 2003.

[99] C. A. Flanagan, "A GPCR that is not 'DRY'” Molecular Pharmacology, vol. 68, no. 1, pp. 1-3, 2005.

[100] L. Arvanitakis, E. Geras-Raaka, A. Varma, M. C. Gershengorn, and E. Cesarman, "Human herpesvirus KSHV encodes a constitutively active G-protein- coupled receptor linked to cell proliferation," Nature, vol. 385, no. 6614, pp. 347-350, 1997.

[101] M. Burger, J. A. Burger, R. C. Hoch, Z. Oades, H. Takamori, and I. U. Schraufstatter, "Point mutation causing constitutive signaling of CXCR2 leads to transforming activity similar to Kaposi's sarcoma herpesvirus-G protein- coupled receptor," Journal of Immunology, vol. 163, no. 4, pp. 2017-2022, 1999.

[102] M. M. Rosenkilde, T. N. Kledal, P. J. Holst, and T. W. Schwartz, "Selective elimination of high constitutive activity or chemokine binding in the human herpesvirus 8 encoded seven transmembrane oncogene ORF74," Journal of Biological Chemistry, vol. 275, no. 34, pp. 26309-26315, 2000.

[103] M. N. Wakeling, D. J. Roy, A. A. Nash, and J. P. Stewart, "Characterization of the murine gammaherpesvirus 68 ORF74 product: a novel oncogenic G protein-coupled receptor," Journal of General Virology, vol. 82, pp. 1187-1197, 2001.

[104] D. Verzijl, C. P. Fitzsimons, M. Van Dijk et al., "Differential activation of murine herpesvirus 68- and Kaposi's sarcomaassociated herpesvirus-encoded ORF74 G protein-coupled receptors by human and murine chemokines," Journal of Virology, vol. 78, no. 7, pp. 3343-3351, 2004.

[105] Y. Isegawa, Z. Ping, K. Nakano, N. Sugimoto, and K. Yamanishi, "Human herpesvirus 6 open reading frame U12 encodes a functional $\beta$ - chemokine receptor," Journal of Virology, vol. 72, no. 7, pp. 6104-6112, 1998.

[106] C. P. Fitzsimons, U. A. Gompels, D. Verzijl et al., "Chemokine-directed trafficking of receptor stimulus to different $G$ proteins: selective inducible and constitutive signaling by human herpesvirus 6-encoded chemokine receptor U51," Molecular Pharmacology, vol. 69, no. 3, pp. 888-898, 2006.

[107] R. Case, E. Sharp, T. Benned-Jensen, M. M. Rosenkilde, N. Davis-Poynter, and H. E. Farrell, "Functional analysis of the murine cytomegalovirus chemokine receptor homologue M33: ablation of constitutive signaling is associated with an attenuated phenotype in vivo," Journal of Virology, vol. 82, no. 4, pp. 1884-1898, 2008.

[108] Y. K. Gruijthuijsen, E. V. H. Beuken, M. J. Smit, R. Leurs, C. A. Bruggeman, and C. Vink, "Mutational analysis of the R33encoded $\mathrm{G}$ protein-coupled receptor of rat cytomegalovirus: identification of amino acid residues critical for cellular localization and ligand-independent signalling," Journal of General Virology, vol. 85, pp. 897-909, 2004.

[109] S. M. Rodems and D. H. Spector, "Extracellular signalregulated kinase activity is sustained early during human cytomegalovirus infection," Journal of Virology, vol. 72, no. 11, pp. 9173-9180, 1998.
[110] J. Vomaske, R. M. Melnychuk, P. P. Smith et al., "Differential ligand binding to a human cytomegalovirus chemokine receptor determines cell type-specific motility," PLoS Pathogens, vol. 5, no. 2, Article ID e1000304, 2009.

[111] O. Pleskoff, P. Casarosa, L. Verneuil et al., "The human cytomegalovirus-encoded chemokine receptor US28 induces caspase-dependent apoptosis," FEBS Journal, vol. 272, no. 16, pp. 4163-4177, 2005.

[112] D. Maussang, D. Verzijl, M. Van Walsum et al., "Human cytomegalovirus-encoded chemokine receptor US28 promotes tumorigenesis," Proceedings of the National Academy of Sciences of the United States of America, vol. 103, no. 35, pp. 13068-13073, 2006.

[113] D. Maussang, E. Langemeijer, C. P. Fitzsimons et al., "The human cytomegalovirus-encoded chemokine receptor US28 promotes angiogenesis and tumor formation via cyclooxygenase-2," Cancer Research, vol. 69, no. 7, pp. 28612869, 2009.

[114] E. Slinger, D. Maussang, A. Schreiber et al., "HCMV-encoded chemokine receptor US28 mediates proliferative signaling through the IL-6-STAT3 axis," Science Signaling, vol. 3, no. 133, Article ID ra58, 2010.

[115] P. Ranganathan, P. A. Clark, J. S. Kuo, M. S. Salamat, and R. F. Kalejta, "Significant association of multiple human cytomegalovirus genomic loci with glioblastoma multiforme samples," Journal of Virology, vol. 86, no. 2, pp. 854-864, 2012.

[116] K. G. Lucas, L. Bao, R. Bruggeman, K. Dunham, and C. Specht, "The detection of CMV pp65 and IE1 in glioblastoma multiforme," Journal of Neuro-Oncology, vol. 103, no. 2, pp. 231-238, 2011.

[117] C. S. Cobbs, "Evolving evidence implicates cytomegalovirus as a promoter of malignant glioma pathogenesis," Herpesviridae, vol. 2, no. 1, p. 10, 2011.

[118] K. Dziurzynski, J. Wei, W. Qiao et al., "Glioma-associated cytomegalovirus mediates subversion of the monocyte lineage to a tumor propagating phenotype," Clinical Cancer Research, vol. 17, no. 14, pp. 4642-4649, 2011.

[119] R. Lyngaa, K. Nørregaard, M. Kristensen, V. Kubale, M. M. Rosenkilde, and T. N. Kledal, "Cell transformation mediated by the Epstein-Barr virus G protein-coupled receptor BILF1 is dependent on constitutive signaling," Oncogene, vol. 29, no. 31, pp. 4388-4398, 2010.

[120] A. J. Butcher, R. Prihandoko, K. C. Kong et al., "Differential G-protein-coupled receptor phosphorylation provides evidence for a signaling bar code," Journal of Biological Chemistry, vol. 286, no. 13, pp. 11506-11518, 2011.

[121] A. J. Butcher, K. C. Kong, R. Prihandoko, and A. B. Tobin, "Physiological role of g-protein coupled receptor phosphorylation," Handbook of Experimental Pharmacology, vol. 208, pp. 79-94, 2012.

[122] S. K. Shenoy and R. J. Lefkowitz, "Multifaceted roles of $\beta$-arrestins in the regulation of seven-membrane-spanning receptor trafficking and signalling," Biochemical Journal, vol. 375, pp. 503-515, 2003.

[123] S. K. Shenoy, P. H. McDonald, T. A. Kohout, and R. J. Lefkowitz, "Regulation of receptor fate by ubiquitination of activated $\beta 2$-adrenergic receptor and $\beta$-arrestin," Science, vol. 294, no. 5545, pp. 1307-1313, 2001.

[124] A. Fraile-Ramos, A. Pelchen-Matthews, T. N. Kledal, H. Browne, T. W. Schwartz, and M. Marsh, "Localization of HCMV UL33 and US27 in endocytic compartments and viral membranes," Traffic, vol. 3, no. 3, pp. 218-232, 2002. 
[125] E. A. Berger, "HIV entry and tropism: the chemokine receptor connection," AIDS, vol. 11, pp. S3-16, 1997.

[126] A. Fraile-Ramos, T. N. Kledal, A. Pelchen-Matthews, K. Bowers, T. W. Schwartz, and M. Marsh, "The human cytomegalovirus US28 protein is located in endocytic vesicles and undergoes constitutive endocytosis and recycling," Molecular Biology of the Cell, vol. 12, no. 6, pp. 1737-1749, 2001.

[127] A. Fraile-Ramos, T. A. Kohout, M. Waldhoer, and M. Marsh, "Endocytosis of the viral chemokine receptor US28 does not require beta-arrestins but is dependent on the clathrinmediated pathway," Traffic, vol. 4, no. 4, pp. 243-253, 2003.

[128] G. Alkhatib, C. Combadiere, C. C. Broder et al., "CC CKR5: a RANTES, MIP- $1 \alpha$, MIP- $1 \beta$ receptor as a fusion cofactor for macrophage-tropic HIV-1," Science, vol. 272, no. 5270, pp. 1955-1958, 1996.

[129] Y. Feng, C. C. Broder, P. E. Kennedy, and E. A. Berger, "HIV-1 entry cofactor: functional cDNA cloning of a seventransmembrane, G protein-coupled receptor," Science, vol. 272, no. 5263, pp. 872-877, 1996.

[130] C.-Z. Dong, S. Tian, N. Madani et al., "Role of CXCR4 internalization in the anti-HIV activity of stromal cellderived factor- $1 \alpha$ probed by a novel synthetically and modularly modified-chemokine analog," Experimental Biology and Medicine, vol. 236, no. 12, pp. 1413-1419, 2011.

[131] N. Signoret, J. Oldridge, A. Pelchen-Matthews et al., "Phorbol esters and SDF-1 induce rapid endocytosis and down modulation of the chemokine receptor CXCR4," Journal of Cell Biology, vol. 139, no. 3, pp. 651-664, 1997.

[132] N. Signoret, M. M. Rosenkilde, P. J. Klasse et al., "Differential regulation of CXCR4 and CCR5 endocytosis," Journal of Cell Science, vol. 111, pp. 2819-2830, 1998.

[133] P. J. Klasse, M. M. Rosenkilde, N. Signoret, A. PelchenMatthews, T. W. Schwartz, and M. Marsh, "CD4-chemokine receptor hybrids in human immunodeficiency virus type 1 infection," Journal of Virology, vol. 73, no. 9, pp. 7453-7466, 1999.

[134] M. Oppermann, M. Mack, A. E. I. Proudfoot, and H. Olbrich, "Differential effects of CC chemokines on CC chemokine receptor 5 (CCR5) phosphorylation and identification of phosphorylation sites on the CCR5 carboxyl terminus," Journal of Biological Chemistry, vol. 274, no. 13, pp. 88758885, 1999.

[135] I. Aramori, J. Zhang, S. S. G. Ferguson, P. D. Bieniasz, B. R. Cullen, and M. G. Caron, "Molecular mechanism of desensitization of the chemokine receptor CCR-5: receptor signaling and internalization are dissociable from its role as an HIV-1 co-receptor," The EMBO Journal, vol. 16, no. 15, pp. 4606-4616, 1997.

[136] K. Kraft, H. Olbrich, I. Majoul, M. Mack, A. Proudfoot, and M. Oppermann, "Characterization of sequence determinants within the carboxyl-terminal domain of chemokine receptor CCR5 that regulate signaling and receptor internalization," Journal of Biological Chemistry, vol. 276, no. 37, pp. 3440834418, 2001.

[137] S. Venkatesan, A. Petrovic, M. Locati, Y. O. Kim, D. Weissman, and P. M. Murphy, "A membrane-proximal basic domain and cysteine cluster in the C-terminal tail of CCR5 constitute a bipartite motif critical for cell surface expression," Journal of Biological Chemistry, vol. 276, no. 43, pp. 40133-40145, 2001.

[138] M. J. Orsini, J. L. Parent, S. J. Mundell, and J. L. Benovic, "Trafficking of the HIV coreceptor CXCR4. Role of arrestins and identification of residues in the C-terminal tail that mediate receptor internalization," Journal of Biological Chemistry, vol. 274, no. 43, pp. 31076-31086, 1999.

[139] B. Haribabu, R. M. Richardson, I. Fisher et al., "Regulation of human chemokine receptors CXCR4: role of phosphorylation in desensitization and internalization," Journal of Biological Chemistry, vol. 272, no. 45, pp. 28726-28731, 1997.

[140] T. Kawai, U. Choi, N. L. Whiting-Theobald et al., "Enhanced function with decreased internalization of carboxy-terminus truncated CXCR4 responsible for WHIM syndrome," Experimental Hematology, vol. 33, no. 4, pp. 460-468, 2005.

[141] M. P. Stropes, O. D. Schneider, W. A. Zagorski, J. L. C. Miller, and W. E. Miller, "The carboxy-terminal tail of human cytomegalovirus (HCMV) US28 regulates both chemokineindependent and chemokine-dependent signaling in HCMVinfected cells," Journal of Virology, vol. 83, no. 19, pp. 1001610027, 2009.

[142] B. Bodaghi, T. R. Jones, D. Zipeto et al., "Chemokine sequestration by viral chemoreceptors as a novel viral escape strategy: withdrawal of chemokines from the environment of cytomegalovirus- infected cells," Journal of Experimental Medicine, vol. 188, no. 5, pp. 855-866, 1998.

[143] T. Mokros, A. Rehm, J. Droese, M. Oppermann, M. Lipp, and U. E. Höpken, "Surface expression and endocytosis of the human cytomegalovirus-encoded chemokine receptor US28 is regulated by Agonist-independent phosphorylation," Journal of Biological Chemistry, vol. 277, no. 47, pp. 4512245128, 2002.

[144] M. Waldhoer, P. Casarosa, M. M. Rosenkilde et al., "The carboxyl terminus of human cytomegalovirus-encoded 7 transmembrane receptor US28 camouflages agonism by mediating constitutive endocytosis," Journal of Biological Chemistry, vol. 278, no. 21, pp. 19473-19482, 2003.

[145] L. K. Stapleton, K. L. Arnolds, A. P. Lares, T. M. Devito, and J. V. Spencer, "Receptor chimeras demonstrate that the Cterminal domain of the human cytomegalovirus US27 gene product is necessary and sufficient for intracellular receptor localization," Virology Journal, vol. 9, no. 1, article 42, 2012.

[146] C. Liu, G. Sandford, G. Fei, and J. Nicholas, "Galpha protein selectivity determinant specified by a viral chemokine receptor-conserved region in the $\mathrm{C}$ tail of the human herpesvirus 8 g protein-coupled receptor," Journal of Virology, vol. 78, no. 5, pp. 2460-2471, 2004.

[147] M. Schwarz and P. M. Murphy, "Kaposi's sarcoma-associated herpesvirus $G$ protein-coupled receptor constitutively activates $\mathrm{NF}-\kappa \mathrm{B}$ and induces proinflammatory cytokine and chemokine production via a C-terminal signaling determinant," Journal of Immunology, vol. 167, no. 1, pp. 505-513, 2001.

[148] D. Verzijl, L. Pardo, M. Van Dijk et al., "Helix 8 of the viral chemokine receptor ORF74 directs chemokine binding," Journal of Biological Chemistry, vol. 281, no. 46, pp. 3532735335, 2006.

[149] J. Zuo, L. L. Quinn, J. Tamblyn et al., "The Epstein-Barr virus-encoded BILF1 protein modulates immune recognition of endogenously processed antigen by targeting major histocompatibility complex class I molecules trafficking on both the exocytic and endocytic pathways," Journal of Virology, vol. 85, no. 4, pp. 1604-1614, 2011. 

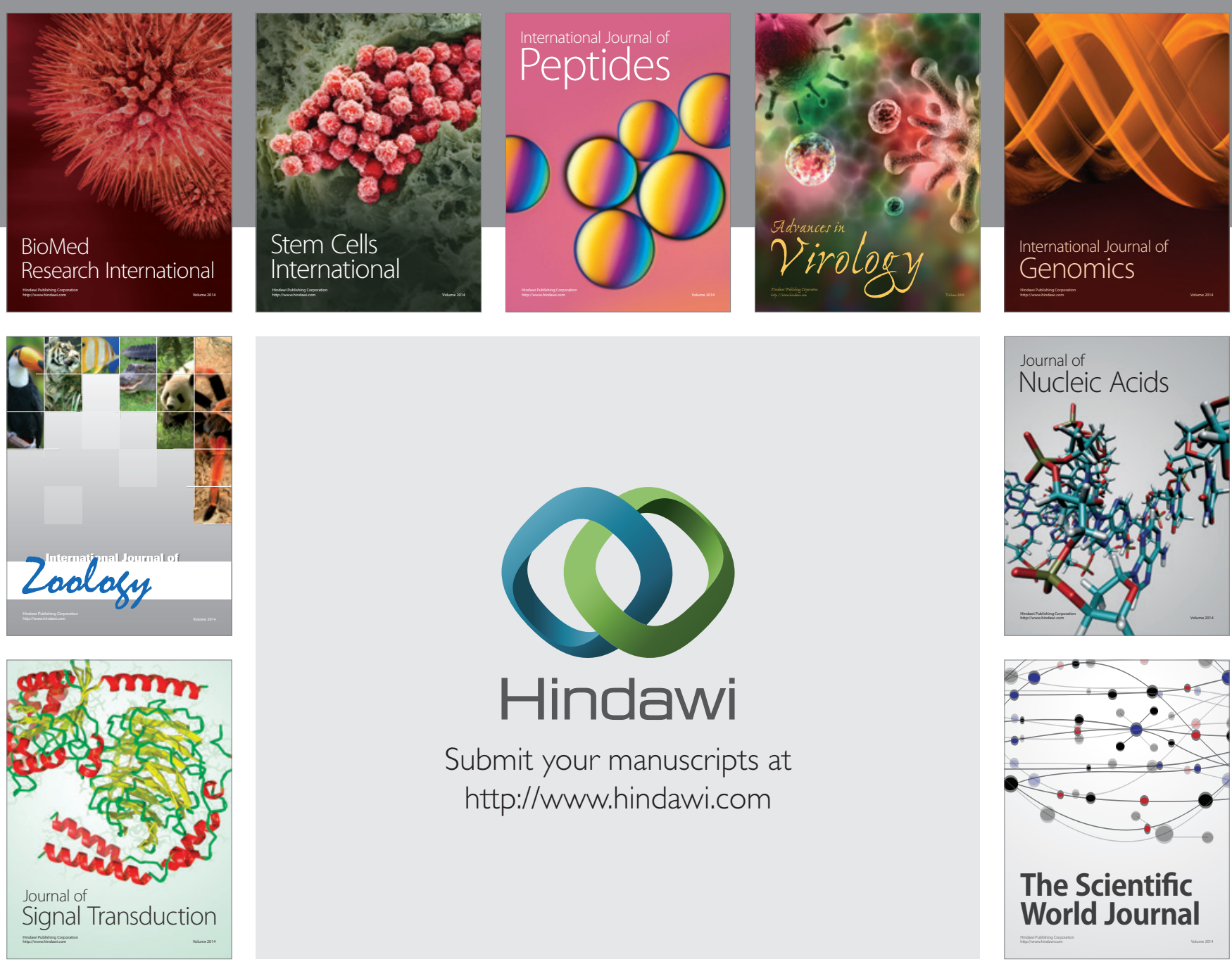

Submit your manuscripts at

http://www.hindawi.com
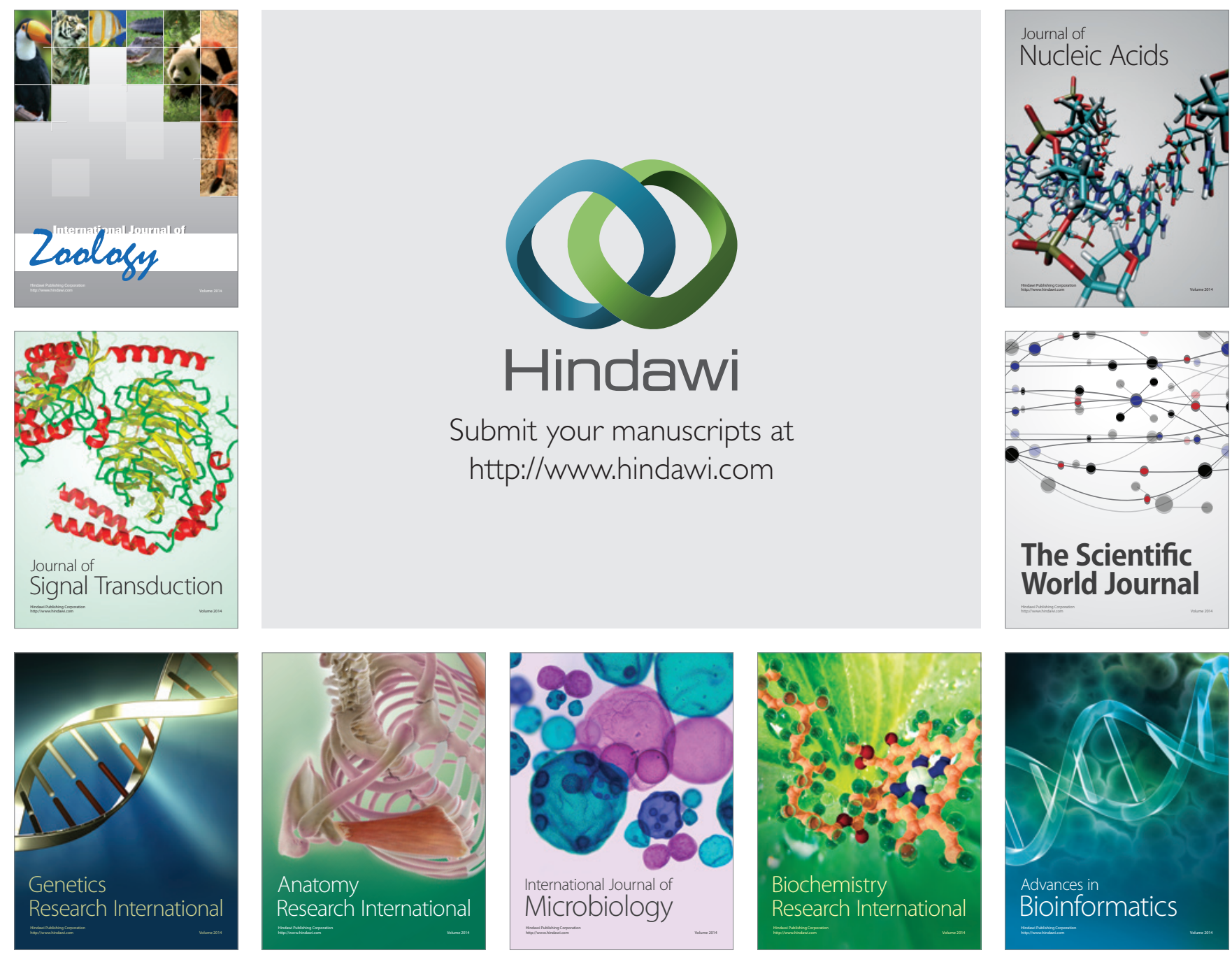

The Scientific World Journal
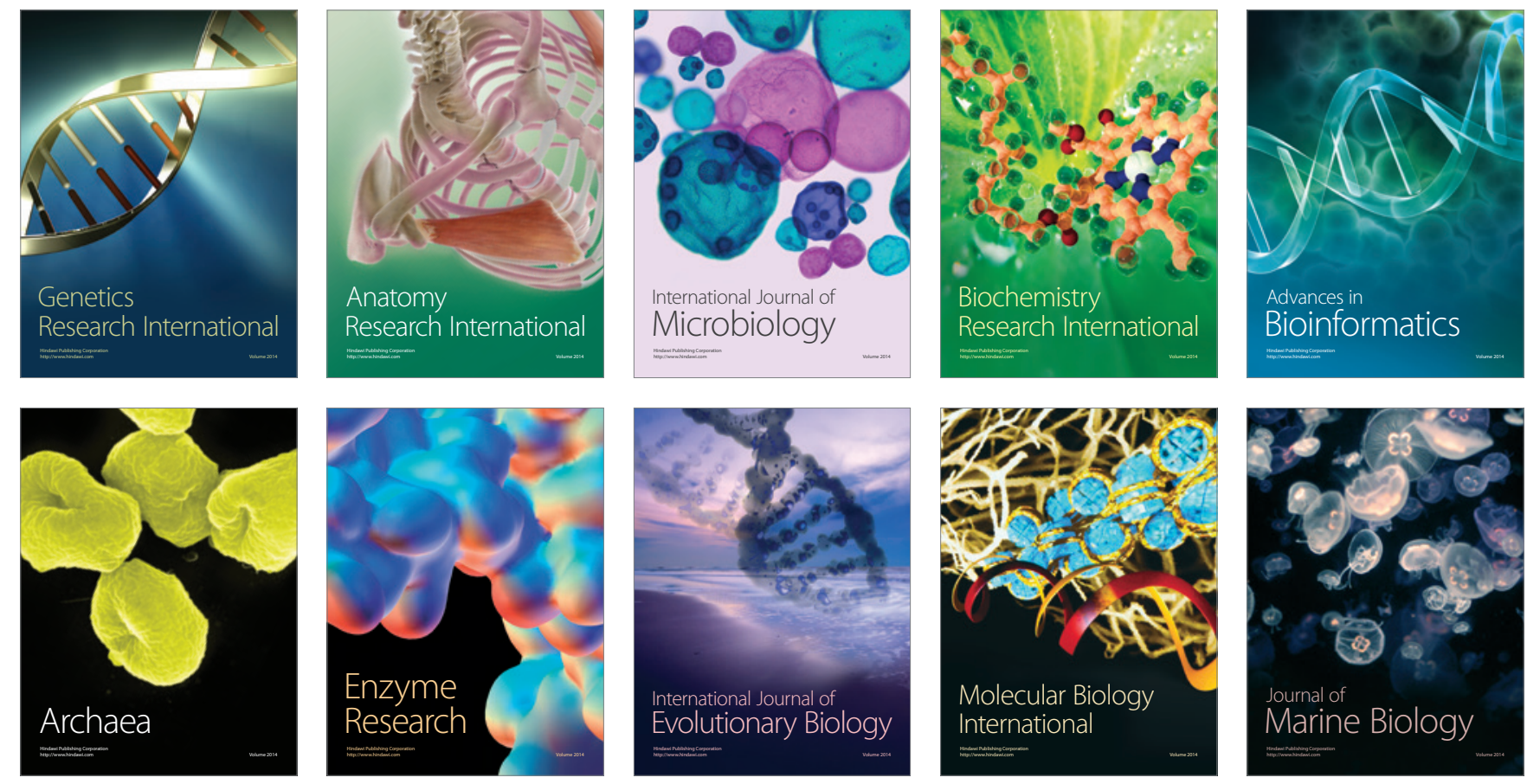